\title{
CO2 fluxes in the Northeast Atlantic Ocean based on measurements from a surface ocean observation platform
}

\author{
Curbelo-Hernández D 1, González-Dávila M 1, ${ }^{\text {, }}$ Gonzalez Ag ${ }^{1}$, González-Santana D 1,2, \\ Santana-Casiano $\mathrm{Jm}^{1}$
}

1 Instituto de Oceanografía y Cambio Global, IOCAG, Universidad de Las Palmas de Gran Canaria, 35017, Spain

2 Univ Brest, CNRS IRD, IFREMER, LEMAR, F-29280 Plouzane, France

* Corresponding author : M. González-Dávila, email address : melchor.gonzalez@ulpgc.es

\begin{abstract}
:
The seasonal and spatial variability of the $\mathrm{CO} 2$ system parameters and $\mathrm{CO} 2$ air-sea exchange were studied in the Northeast Atlantic Ocean between the northwest African coastal upwelling and the oligotrophic open-ocean waters of the North Atlantic subtropical gyre. Data was collected aboard a volunteer observing ship from February 2019 to February 2020. The seasonal and spatial variability of $\mathrm{CO} 2$ fugacity in seawater ( $\mathrm{fCO} 2, \mathrm{sw}$ ) was strongly driven by the seasonal temperature variation, which increased with latitude and was lower throughout the year in coastal regions where the upwelling and offshore transport was more intense. The thermal to biological effect ratio (T/B) was approximately 2 , with minimum values along the African coastline related to higher biological activity in the upwelled waters. The fCO2,sw increased from winter to summer by $11.84 \pm 0.28 \mu \mathrm{atm}^{\circ} \mathrm{C}-1$ on the inter-island routes and by $11.71 \pm 0.25 \mu \mathrm{atm}^{\circ} \mathrm{C}-1$ along the northwest African continental shelf. The seasonality of total inorganic carbon normalized to constant salinity of 36.7 (NCT) was studied throughout the region. The effect of biological processes and calcification/dissolution on NCT between February and October represented $>90 \%$ of the reduction of inorganic carbon while air-sea exchange described $<6 \%$. The seasonality of air-sea $\mathrm{CO} 2$ exchange was controlled by temperature. The surface waters of the entire region acted as a $\mathrm{CO} 2$ sink during the cold months and as a $\mathrm{CO} 2$ source during the warm months. The Canary basin acted as a net sink of $-0.26 \pm 0.04 \mathrm{molC} \mathrm{m}-2 \mathrm{yr}-1$. The northwest African continental shelf behaved as a stronger sink at $-0.48 \pm 0.09 \mathrm{molC} \mathrm{m}-2 \mathrm{yr}-1$. The calculated average $\mathrm{CO} 2$ flux for the entire area was $-2.65 \pm 0.44 \mathrm{TgCO} 2 \mathrm{yr}-1(-0.72 \pm 0.12 \mathrm{TgC} \mathrm{yr}-1)$.
\end{abstract}




\section{Graphical abstract}

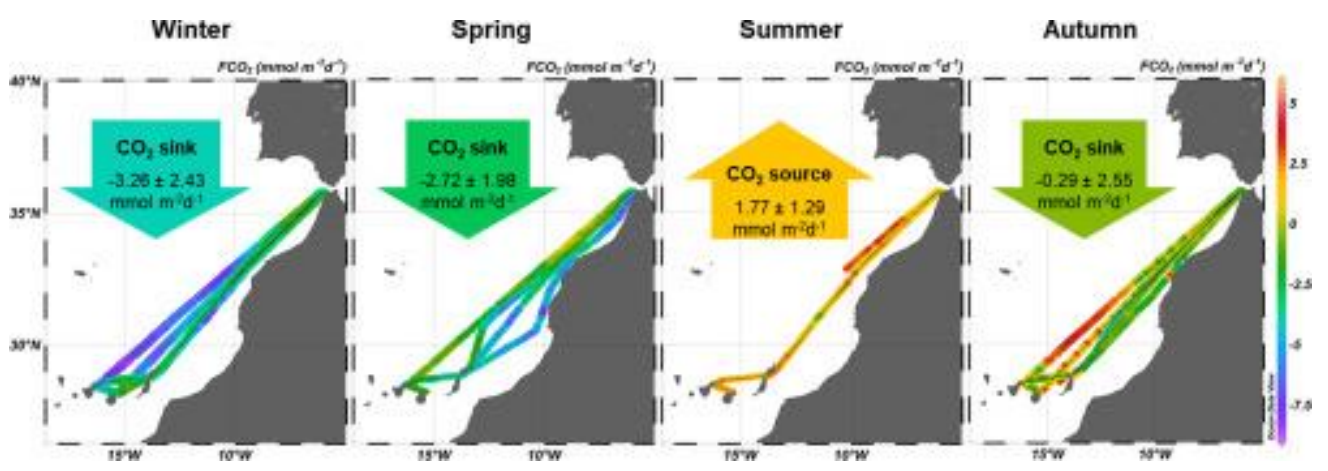

\section{Highlights}

- The SST controls the seasonal and spatial variation of $\mathrm{CO}_{2}$ fugacity and fluxes. shows spatial variability associated with upwelling influence. $\mathrm{NC}$ T variation was mainly governed by biological activity and slightly affected by air-sea fluxes. During 2019, the Northeast Atlantic region behaved as an annual $\mathrm{CO}_{2}$ sink of $-2.65 \pm 0.44 \mathrm{Tg} \mathrm{CO}_{2} \mathrm{yr}^{-1}$. $\downarrow$ VOS lines are a powerful tool to study de $\mathrm{CO}_{2}$ system and fluxes in the coastal surface area.

Keywords : CO2 system, air-sea CO2 exchange, Northeast Atlantic, northwest African coastal upwelling, surface ocean observation platform. 


\section{Introduction}

The Earth's oceans are an important carbon sink, removing about one third of the total $\mathrm{CO}_{2}$ emissions from the atmosphere (Friedlingstein et al., 2019; Gruber et al., 2019; Le Quéré et al., 2018). A decrease in $\mathrm{pH}$ and an alteration of the fundamanı! chemical balances have been observed in the global ocean as a consequence of $t^{1} 1 \mathrm{~s} \sim \mathbf{U}_{2}$ uptake (Bates et al., 2014; Doney et al., 2009), affecting marine ecosystems and liv/ $\mathrm{h}_{\Upsilon_{c}}$ organisms (Gattuso and Hansson, 2011). In this context, coastal regions and continer al helves, which are biogeochemically active regions, play an important role in the $1 a^{1}$ carbon cycle. They are characterised by carbon fixation and remineralisation rati $\mathrm{c}$ '. 1 gher than the global average and by high spatial and temporal variability of the $\mathrm{CC}_{\angle}$ fluxes (Borges et al., 2005; Cai et al., 2006; Frankignoulle and Borges, 2001 Sh ${ }^{\prime}$.wick et al., 2010; 2011). These regions have been largely ignored in the Global $\mathrm{C}$ arbon Budget due to the limited number of local and regional studies and the resulting $r \sim r$ representation in global models. Borges et al. (2005) highlighted the importá. - e of coastal areas in the Global Carbon Budget. They remarked that the inclusion of coastal zones increased the estimated global ocean $\mathrm{CO}_{2}$ sinks by $57 \%$ at high latitudes and by $15 \%$ in mid-latitudes, while $\mathrm{CO}_{2}$ emissions from the ocean to the atmosphere increased by $13 \%$ in tropical and subtropical regions. This is a consequence of the latitudinal variability of air-sea $\mathrm{CO}_{2}$ exchange on the continental shelves: medium- and high-latitude

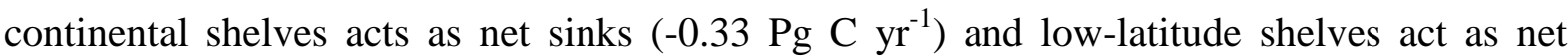
sources (0.11 Pg C $\mathrm{yr}^{-1}$ ) (Borges et al., 2005; Cai et al., 2006; Chen et al., 2013). The net carbon flux on the continental shelves ranges between $\sim 0.25 \mathrm{Pg} \mathrm{C} \mathrm{yr}^{-1}$ (Cai, 2011) and $0.4 \mathrm{Pg}$ 


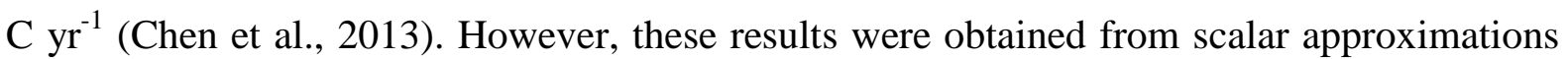
and interpolations and show a high degree of uncertainty due to the limited available data. A higher number of regional carbon cycle studies with a high measurement frequency are required in coastal areas and continental shelves in order to improve the characterization of the Global Carbon Budget.

The North Atlantic has been recognized as one of the largest ocean sinks of natural and anthropogenic $\mathrm{CO}_{2}$, especially at subtropical and subpolar latitudes (e.g. Jing et al., 2019; Khatiwala et al., 2013; Leseurre et al., 2020; Sabine et al. गn..; Takahashi et al., 2002; Takahashi et al., 2009). This basin stores $23 \%$ of the 10 al oceanic anthropogenic $\mathrm{CO}_{2}$ despite covering only $15 \%$ of the global ocean area dro th high vertical integration driven by deep water mass formation processes and thermor.alı. - circulation (THC) (Sabine et al., 2004). The greatest source of uncertainty in $h r$ North Atlantic Carbon Budget is the contribution of the seasonal and spatia v? iability of $\mathrm{CO}_{2}$ system and air-sea exchange in coastal waters and on continental sht: ${ }^{\prime}$ es, especially in the Eastern Boundary Upwelling Systems.

The seasonal variability of $\mathrm{C}^{-}$' on the European continental shelf was studied by using a

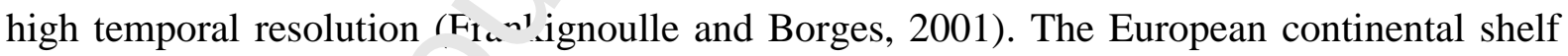

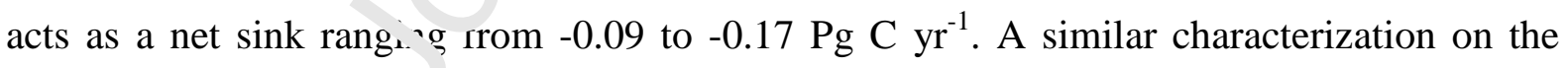
African continental shelf in the North Atlantic is difficult to perform due to the low temporal resolution of the available regional studies. Studies in the Northeast Atlantic are essential to understand the biogeochemical dynamics in the coastal transition region of the northwest African upwelling, with high rates of primary production and carbon recycling and export (Huntsman and Barber, 1977; Jewell, 1994). The strong influence on the intensity and location of the Canary Current (Pelegrí et al., 2005), the effect of the $\mathrm{CO}_{2}$ continental pump (Tsunogai et al., 1999) and the oligotrophic ocean waters of the North Atlantic subtropical 
gyre should also be considered. Offshore export of the upwelling physicochemical characteristics through superficial cold-water filaments can reach several hundred kilometres during the warm months, coinciding with the maximum intensity of the upwelling between the Canary Islands and the Strait of Gibraltar (Pelegrí et al., 2005). The seasonal variations of the $\mathrm{CO}_{2}$ parameters in the Northeast Atlantic subtropical gyre have been studied at the European Station of Oceanic Time Series (ESTOC) (González-Dávila et al., 2003; GonzálezDávila et al., 2010; Santana-Casiano et al., 2007). The results show the effects of seasonality, mainly due to temperature dependence of the $\mathrm{CO}_{2}$ system raran eters at the ESTOC site, acting as a $\mathrm{CO}_{2}$ sink during the cold months (Decembe $-\mathrm{N} \cdot \mathrm{y}$ ) and as a source during the warm months (June-November) (González-Dávila et a1 _?93; Santana-Casiano et al., 2001). The aim of this study was to analyse the behaviour $\mathrm{An}$ distribution of $\mathrm{CO}_{2}$ in the Northeast Atlantic region between the Canary Islands ar $d_{2}$ e strait of Gibraltar from February 2019 to February 2020. The first objective wa tr obtain high frequency measurements and data through autonomous monitoring syste.?s deployed on a surface ocean observing platform (SOOP) on a volunteer observing $\mathrm{hi}_{1} 、$ VOS), SOOP CanOA-VOS. Samples were analysed on the Canary basin and on th. Atrican continental shelf (Fig. 1) and discussed considering surface data collected by nth - JOS and research vessels in the Northeast Atlantic $\left(26-38^{\circ} \mathrm{N}\right.$, $\left.5-20^{\circ} \mathrm{W}\right)($ SOCAT v20 \?).

\section{Material and methods}

Seasonal variability in the distribution and air-sea exchange of $\mathrm{CO}_{2}$ was studied in the oceanic waters of the Canary archipelago and in the transitional waters between the northwest African coastal upwelling and the oceanic waters of the North Atlantic subtropical gyre. The high spatial and temporal data was obtained using automated underway systems aboard the SOOP CanOA container ship RENATE P (IMO: 9144718), a VOS operated by Nisa Maritime. The vessel has a usual route which stops at three ports in the Canary Islands (Las 
Palmas de Gran Canaria $\left(28.1319^{\circ} \mathrm{N}, 15.4185^{\circ} \mathrm{W}\right.$; GC), Santa Cruz de Tenerife $\left(28.4867^{\circ} \mathrm{N}\right.$, $16.2284^{\circ} \mathrm{W}$; TNF), Arrecife $\left(28.9682^{\circ} \mathrm{N}, 13.5294^{\circ} \mathrm{W}\right.$; LNZ), and travel northward towards the Mediterranean Sea crossing the Strait of Gibraltar (SG). The data was collected with a frequency of two weeks (time required to perform a round trip) at the port of Las Palmas de Gran Canaria. This study focused on the Northeast Atlantic Ocean and was divided into two regions. First, the oceanographic environment of the Canary Islands, between Gran Canaria and Tenerife (GC-TNF) and between Tenerife and Lanzarote (TNF-LNZ). Second, the coastal region and transition to ocean waters of northwest Afrim $\iota$ tween the Canary Islands and the Strait of Gibraltar (CI-SG).

\subsection{Temperature, salinity and $\mathrm{xCO}_{2}$ measurements}

An automated underway seawater and low atr $\mathrm{os}_{\mathrm{h}}$ heric $\mathrm{CO}_{2}$ molar fraction $\left(\mathrm{xCO}_{2}\right)$ measurement system, developed by Craig Nei1 . nd commercialized by General Oceanics ${ }^{\mathrm{TM}}$, with additional sensors of temperature, al' aity and oxygen, was installed inside the engine room of the RENATE P container sh1 ${ }_{\uparrow}$ The system combines an air and water equilibrator with an infrared analyser for deter+iol. (Pierrot et al., 2009).

The system calibration was $\iota^{a r i e d ~ o u t ~ a u t o m a t i c a l l y ~ o n ~ d e p a r t u r e ~ f r o m ~ a n d ~ a r r i v a l ~ a t ~ e a c h ~}$ port, and periodically e sry three hours during the ship's journey, with four standard gases (0 ppm, $249.37 \mathrm{ppm}, 397.83 \mathrm{ppm}$ and $524.74 \mathrm{ppm}$ ) provided by the National Ocean and Atmospheric Administration (NOAA) and traceable to the World Meteorological Organization (WMO).

Measurements of $\mathrm{xCO}_{2}(\mathrm{ppm})$ in seawater with frequencies of 2-3 minutes were performed by extracting seawater from the ship's supply at flow rates greater than $60 \mathrm{~L} \mathrm{~min}^{-1}$ and passing it through a plexiglass equilibrator at flow rates ranging between 3 and $4 \mathrm{~L} \mathrm{~min}^{-1}$. The system also performs three $\mathrm{xCO}_{2}$ measurements in low atmosphere per hour used to compute 
atmospheric $\mathrm{CO}_{2}$ content. In both cases, a non-dispersive infrared analyser built by LICOR ${ }^{\circledR}$ (initially the 6262 model and after October 2019, a 7000 model) were used for the detection of $\mathrm{xCO}_{2}$.

The sea surface temperature (SST, in ${ }^{\circ} \mathrm{C}$ ) was measured using a SBE38 thermometer placed at the main seawater intake not affected by the ship engine. A SBE21 thermosalinograph (TSG), with an estimated error of $0.01^{\circ} \mathrm{C}$, was located near the $\mathrm{xCO}_{2}$ system. In addition, the temperature in the equilibrator was monitored due to the high sensitivity of $\mathrm{xCO}_{2}$ to temperature changes. Sea surface salinity (SSS) was measurnd w th a manually calibrated SBE21 thermosalinograph, with an estimated error of $\therefore$. .47 . Atmospheric pressure was measured by the deck's transducer (these pressure raro.ts being different in the order of millibars with the pressure near the $\mathrm{xCO}_{2}$ system, inside the ship).

Due to technical problems with the measurem $n_{\mathfrak{\imath}}$ andipment aboard the VOS, no temperature, salinity or $\mathrm{xCO}_{2}$ measurements were $\mathrm{h}^{\mathrm{t}}$, ned during March 2019 (problems with water intake), during the second half of Augu +2019 (problems with LICOR flow) and on a limited number of return journeys from th $=\mathrm{DC}^{\text {+t }}$ of Barcelona.

\subsection{Variable determination}

This study followed the $u^{t^{t}}$. collection methodology, quality control and calculation procedures as publisht 11 the updated version of the DOE method manual for carbon dioxide analysis in seawater (Dickson et al., 2007). From the measured and corrected values, the fugacity of $\mathrm{CO}_{2}$ was calculated in seawater $\left(f \mathrm{CO}_{2, \mathrm{sw}}\right)$ and the lower atmosphere $\left(f \mathrm{CO}_{2, \mathrm{~atm}}\right)$ following the procedure as indicated by Pierrot et al. (2009).

The partial effect of thermal and non-thermal factors on seasonal variation of $f \mathrm{CO}_{2, \mathrm{sw}}$ was studied using the equations presented by Takahashi et al. (2002), with the temperature effects on $f \mathrm{CO}_{2, \mathrm{sw}}$ for isochemical seawater of $0.0423^{\circ} \mathrm{C}^{-1}$ determined experimentally by Takahashi et al. (1993) for a North Atlantic surface water sample. To study the non-thermal effect, termed 
in this work as biological effect, $f \mathrm{CO}_{2, \mathrm{sw}}$ was normalized to the average temperature (Eq. 1$)$ to remove the temperature effect. The biological effect was obtained from the seasonal amplitude of the normalized $f \mathrm{CO}_{2, \mathrm{sw}}$ (Eq. 2). The thermal effect was calculated by computing the average value of $f \mathrm{CO}_{2, \mathrm{sw}}$ to the observed temperature (Eq. 3) and determining its seasonal amplitude (Eq. 4). The relative importance of thermal and biological effects was expressed by the $\mathrm{T} / \mathrm{B}$ ratio $\left[\left(\Delta f \mathrm{CO}_{2}\right)_{\text {temp }} /\left(\Delta f \mathrm{CO}_{2}\right)_{\text {bio }}\right]$, where values greater than 1 indicated that the temperature effect dominated over the biological effect.

$$
\begin{aligned}
& f \mathrm{CO}_{2}\left(\mathrm{~T}_{\text {mean }}\right)=\left(f \mathrm{CO}_{2}\right)_{\text {obs }} \cdot \exp \left[0.0423\left(\mathrm{~T}_{\text {mean }}-\mathrm{T}_{\text {, ss. }}\right)(1)\right. \\
& \left(\Delta f \mathrm{CO}_{2}\right)_{\text {bio }}=\left[f \mathrm{CO}_{2}\left(\mathrm{~T}_{\text {mean }}\right)\right]_{\max }-\left[f \mathrm{CO}_{2}\left(\mathrm{~T}_{\text {me; } \mathrm{n}}\right)_{\mathrm{n} \text { in }}(2)\right. \\
& f \mathrm{CO}_{2}\left(\mathrm{~T}_{\mathrm{obs}}\right)=\left(f \mathrm{CO}_{2}\right)_{\text {mean }} \cdot \exp \left[0.0423\left(\mathrm{~T}_{\mathrm{o}^{\prime}, \mathrm{s}}-\mathrm{T}_{\text {mean }}\right)\right] \quad(3)\left(\Delta f \mathrm{CO}_{2}\right)_{\text {temp }}= \\
& {\left[f \mathrm{CO}_{2}\left(\mathrm{~T}_{\mathrm{obs}}\right)\right]_{\max }-\left[f \mathrm{CO}_{2}\left(\mathrm{~T}_{\mathrm{obs}}\right)\right]_{\min }(4)}
\end{aligned}
$$

The $\mathrm{CO}_{2}$ fluxes $\left(\mathrm{FCO}_{2}\right)$ were determined usinc Ey. J:

$$
\mathrm{FCO}_{2}=0.24 \cdot \mathrm{S} \cdot k \cdot \Delta f \mathrm{CO}_{2}(5)
$$

where 0.24 is a conversion factor to exp $\backsim s$ data in $m m o l m^{-2} \mathrm{~d}^{-1} ; S$ is the solubility of $\mathrm{CO}_{2}$ in seawater and $\Delta f \mathrm{CO}_{2}$ is the $\operatorname{dif}^{f} \mathrm{e}_{1}{ }^{\prime} \mathrm{n}_{\mathrm{e}}$ between the seawater and low atmosphere $f \mathrm{CO}_{2}$ $\left(f \mathrm{CO}_{2, \mathrm{sw}}-f \mathrm{CO}_{2, \mathrm{~atm}}\right)$. Negative tıxes indicate that the ocean acts as an atmospheric $\mathrm{CO}_{2}$ sink, while the positive one : a $a_{\text {I }}$ ate that it behaves as a source. The parameterization of Wanninkhof (2014) was . sed in this study, with $k$ being the gas transfer rate expressed in Eq. 6:

$k=0.251 \cdot \mathrm{w}^{2} \cdot\left(\frac{\mathrm{Sc}}{660}\right)^{-0.5}(6)$

where $w$ is the wind speed $\left(\mathrm{m} \mathrm{s}^{-1}\right)$ and $S c$ is Schmidt number (cinematic viscosity of seawater, divided by the gas diffusion coefficient).

For the $\mathrm{FCO}_{2}$ calculations, daily averages of ocean surface wind speed were used with spatial resolution of $0.25^{\circ} \times 0.25^{\circ}$ derived from the Advanced Scatterometer (ASCAT) and obtained from the Satellite Research and Exploitation Center (CERSAT), at IFREMER, Plouzane 
(France). These wind data were interpolated based on the latitude, longitude and date of the VOS line.

In addition, 54 surface water samples were manually taken along the route during February 2020 with a temporal frequency of 4 hours and in situ measurements of SST and SSS. Samples from the intake seawater line were taken in borosilicate glass bottles, overfilled, preserved with $100 \mu \mathrm{l}$ of saturated $\mathrm{HgCl}_{2}$, kept in darkness and analysed just after arriving at port, in a period less than 2 weeks. The total alkalinity $\left(\mathrm{A}_{\mathrm{T}}, \mu \mathrm{mol} \mathrm{kg}^{-1}\right)$ was determined following the methodology described by Mintrop et al. (2000) *itı an accuracy of $\pm 1.5 \mu \mathrm{mol}$ $\mathrm{kg}^{-1}$. The $\mathrm{A}_{\mathrm{T}}$ was also calculated according to the globa' re tionships of $\mathrm{A}_{\mathrm{T}}$ with SSS and SST in global surface waters described by Lee et al. (ก) $)$, for the subtropical ocean $\left(30^{\circ} \mathrm{S}\right.$ $\left.30^{\circ} \mathrm{N}\right)$ and the North Atlantic $\left(30^{\circ} \mathrm{N}-80^{\circ} \mathrm{N}\right)$ for the mt surements taken on the inter-island routes and on the Canary Islands-Strait of Gib al $\cdot r$ oute, respectively.

The $\mathrm{A}_{\mathrm{T}}$ values obtained from the analys ${ }^{-1}$ s.mples and those calculated presented an average difference of $3.26 \pm 0.28 \mu \mathrm{mol} \mathrm{kg} \mathrm{kg}^{-1}$. L.e to the similarity of both values, $\mathrm{A}_{\mathrm{T}}$ was calculated using the fitting equation of the $1_{i}$ values obtained from discrete samples (Eq. 7) (temperature was not found to :mprove the fitting of the experimental data). It was assumed that the $\mathrm{A}_{\mathrm{T}}-\mathrm{SSS}$ relationship : was valid throughout the full year in tropical and subtropical latitudes (Lee et al., 20い).

$$
A_{T}=1990.5003+456.6909 \cdot(S S S-35)-125.2005 \cdot(S S S-35)^{2}
$$

From the $\mathrm{A}_{\mathrm{T}}$ and $f \mathrm{CO}_{2}$ values, the Total Dissolved Inorganic Carbon $\left(\mathrm{C}_{\mathrm{T}}, \mu \mathrm{mol} \mathrm{kg}{ }^{-1}\right)$ and $\mathrm{pH}$ in total scale $\left(\mathrm{pH}_{\mathrm{T}}\right)$ were computationally determined with the Excel program $\mathrm{CO}_{2}$ sys, using the carbonic acid dissociation constants of Lueker et al. (2000), the $\mathrm{HSO}_{4}$ dissociation constant of Dickson (1990) and the value of $[B]_{\mathrm{I}}$ determined by Lee et al. (2010).

The temporal variation of $\mathrm{C}_{\mathrm{T}}$ was studied using the equation of Sarmiento and Gruber, (2006) (Eq. 8). This equation describes the change in $\mathrm{C}_{\mathrm{T}}$ over time produced by air-sea $\mathrm{CO}_{2}$ 
exchange (EX), horizontal and vertical advection (TRSP), net community production (NCP), horizontal and vertical diffusion (DIFF) and vertical entrainment from the mixed layer (ENT).

$$
\frac{\mathrm{dNC}_{\mathrm{T}}}{\mathrm{dt}}=\left.\frac{\mathrm{dNC}_{\mathrm{T}}}{\mathrm{dt}}\right|_{\mathrm{EX}}+\left.\frac{\mathrm{dNC}_{\mathrm{T}}}{\mathrm{dt}}\right|_{\mathrm{TRSP}}+\left.\frac{\mathrm{dNC}_{\mathrm{T}}}{\mathrm{dt}}\right|_{\mathrm{NCP}}+\left.\frac{\mathrm{dNC}_{\mathrm{T}}}{\mathrm{dt}}\right|_{\text {DIFF }}+\left.\frac{\mathrm{dNC}_{\mathrm{T}}}{\mathrm{dt}}\right|_{\mathrm{ENT}}(8)
$$

The $\mathrm{NC}_{\mathrm{T}}$ variation was studied between February and October, when $\mathrm{C}_{\mathrm{T}}$ decreased and the vertical mixing with the underlying layers of the thermocline were suppressed due to the increase in stratification of the surface waters and the decrfase in the mixed layer depth (MLD) (González-Dávila et al., 2003; Santana-Casiano et al. 2(ֻ7). The observed $\mathrm{C}_{\mathrm{T}}$ growth period between October and February was excluded due $t$, lac s of $\mathrm{C}_{\mathrm{T}}$ values at the bottom of the MLD. The vertical diffusion at BATS (Gruber et ıl., 1998) and ESTOC (González-Dávila et al., 2003) was found to be small. Therefore, the vertical entrainment and diffusion terms were omitted. The change in $\mathrm{NC}_{\mathrm{T}}$ was calcui ted as the difference between two consecutive months and was expressed in $\mathrm{mmol} \mathrm{m}^{-3}$, - onsidering the seawater density. Negative values were indicative of a decrease of $\mathrm{NC}$ - $\eta$ s.rface waters. The air-sea $\mathrm{CO}_{2}$ exchange (EX) term was obtained from the relation: $\mathrm{n}_{1}$ between $\mathrm{FCO}_{2}$ and MLD. The annual climatological monthly MLD was estimated fron a variable temperature threshold of $0.2{ }^{\circ} \mathrm{C}$ and obtained at IFREMER with a spatial res lution of 2 x $2^{\circ}$ (Boyer Montégut et al. 2004, 2007, Mignot et al. 2007). The annual MLL cycle in the Northeast Atlantic was fitted to the harmonic Eq. 9 (latitude was not found to improve the fitting of the monthly MLD data).

$$
M L D=55.55-35.49 \cdot \cos (1.555 \cdot \text { days })-17.59 \cdot \sin (1.555 \cdot \text { days })
$$

The MLD variation range estimated for the ESTOC site (1995-2004) by Santana-Casiano et al. (2007) following Brainerd and Gregg, (1995) was used, with minimum and maximum depth values of 25 and 120 meters for the periods of September-October and FebruaryMarch, respectively, and considering the harmonic decrease of MLD given by Eq. 9 between February and October, 2019. For the horizontal transport component (TRSP), the difference 
between African coastal and oceanic stations selected in a similar latitude range $\left(\Delta \mathrm{NC}_{\mathrm{T}}=\right.$ $\mathrm{NC}_{\mathrm{T}}$, (coastal waters) $-\mathrm{NC}_{\mathrm{T}}$, (oceanic waters) ) were considered. The $\mathrm{NC}_{\mathrm{T}}$ was estimated at both stations taking into account the spatial change in salinity using the $\mathrm{C}_{\mathrm{T}}$-Salinity fit line at the most coastal point. The $\mathrm{NC}_{\mathrm{T}}$ variation by horizontal advection was obtained from the product of $\Delta \mathrm{NC}_{\mathrm{T}}$ and the change in salinity with time at the most oceanic point. Positive values indicated that horizontal transport occurred from coastal upwelled waters to oceanic waters through surface filaments, while negative values indicated that the transport direction was reversed. Lastly, the change in $\mathrm{NC}_{\mathrm{T}}$ due to biological processe $(\mathrm{N} S \mathrm{P})$ considered the sum of changes in calcification/dissolution and photosynthes s/luspiration processes and was obtained directly from Eq. 8. Negative values indirnte ? decrease in $\mathrm{NC}_{\mathrm{T}}$ due to uptake (primary production) and calcification, while positiv $\mathrm{Va}^{\prime}$ 'res reveal an increase in $\mathrm{NC}_{\mathrm{T}}$ due to remineralization and dissolution.

\subsection{Computational methods}

The raw output data was initially filter $d$ eliminating data stations affected by the automatic sampler such as samples measur ${ }^{-1}$ a low water flow rates $\left(<2.5 \mathrm{~L} \mathrm{~min}^{-1}\right)$. The measured $\mathrm{xCO}_{2}$ values were corrected following the indication of Pierrot et al. (2009), linearly interpolating the standard vai ${ }_{s}$ with the $\mathrm{xCO}_{2}$ measurement times and performing a linear regression using a least quares analysis to obtain the corrected $\mathrm{xCO}_{2}$ value in relation to the certified standard values (section 2.2.). The three $f \mathrm{CO}_{2}$,atm values obtained after each calibration were averaged and linearly interpolated with the times of each $f \mathrm{CO}_{2}$,sw. The $\Delta f \mathrm{CO}_{2}$ was computed from the difference between the $f \mathrm{CO}_{2}$,sw and the $f \mathrm{CO}_{2}$, atm values and was used in the $\mathrm{FCO}_{2}$ calculations (section 2.2).

The processed data were divided according to the three journeys of interest: GC-TNF, TNFLNZ and CI-SG. To study the seasonal variability, SST, SSS, $\mathrm{C}_{\mathrm{T}}, f \mathrm{CO}_{2}$,sw, $\mathrm{FCO}_{2}$ and $\mathrm{pH}_{\mathrm{T}}$ values were averaged every $0.05^{\circ}$ of longitude on the GC-TNF route, $0.1^{\circ}$ of longitude on the 
TNF- LNZ route and $0.25^{\circ}$ of latitude on the CI-SG route. The annual and seasonal average were estimated as a function of latitude or longitude, respectively.

The temporal distribution of the variables of interest was calculated using strategic stations on each route. The average physicochemical variables (y) for each location were fitted to harmonic functions (Eq. 10) as a function of time (x) in order to study the seasonal variability and the thermal and non-thermal effect in $f \mathrm{CO}_{2, \mathrm{sw}}$ (Lüger et al., 2004; Takahashi et al., 2002). Coefficients $a-e$ for all the physicochemical variables studied on each route are available in Table A.1.

$$
y=a+b \cdot \cos (2 \pi x)+c \cdot \sin (2 \pi x)+d \cdot \cos (4 \pi x)+e \cdot \sin (4 \pi x)(10)
$$

The results were compared to surface data collected b: ni.ar VOS and research vessels in the Northeast Atlantic $\left(26-38^{\circ} \mathrm{N}, 5-20^{\circ} \mathrm{W}\right)$ and available $t_{\mathrm{t}} \mathrm{t} \cdot$ Surface Ocean $\mathrm{CO}_{2}$ Atlas (SOCAT v2020, https://www.socat.info/) for the Ncitı ^.tlantic, Tropical Atlantic and Coastal Regions. The available SOCAT data $1 \times r$, he period 1991-2019 were used to study the monthly frequency and the annual cycle of $f \mathrm{CO}_{2, \mathrm{sw}}$ in 2019 by considering an interannual rate of increase of $1.8 \mu \mathrm{atm}$ per elar $-\mathrm{d}$; ear (Bates et al., 2014). SST satellite images were obtained from Marine Copernic 'is database (https://marine.copernicus.eu/).

\section{Results}

The determined $\left(f \mathrm{CO}_{2}\right.$, and computed $\left(\mathrm{C}_{\mathrm{T}}, \mathrm{pH}_{\mathrm{T}}\right.$ and $\left.\mathrm{FCO}_{2}\right)$ variables allowed for the determination of the seasonal and spatial variability of the $\mathrm{CO}_{2}$ system and fluxes in the Northeast Atlantic Ocean. We considered three routes: Gran Canaria-Tenerife (GC-TNF), Tenerife-Lanzarote (TNF-LNZ) and Canary Islands-Strait of Gibraltar (CI-SG). The seasonal variability of $f \mathrm{CO}_{2, \mathrm{sw}}$ due to the partial effect of temperature and biological activity at strategic stations on each of the routes received special attention in this study.

The annual and seasonal averages of the carbon variables (Table 1) show that the maximum SST values observed during late summer) on all routes coincided with maximum values of 
$f \mathrm{CO}_{2, \mathrm{sw}}$ and $\mathrm{FCO}_{2}$ and minimum values of $\mathrm{pH}_{\mathrm{T}}$. The seasonal average of $\mathrm{C}_{\mathrm{T}}$ was also minimum at this time of the year (González-Dávila et al., 2003; Santana-Casiano et al., 2007). The average seasonal variation of SST and SSS along the African coast $(3.95 \pm 0.05$ ${ }^{\circ} \mathrm{C}$ and $0.232 \pm 0.004$, respectively) were higher than on the GC-TNF $\left(3.16 \pm 0.01{ }^{\circ} \mathrm{C}\right.$ and $0.080 \pm 0.012$, respectively) and the TNF-LNZ routes $\left(3.23 \pm 0.01{ }^{\circ} \mathrm{C}\right.$ and $0.056 \pm 0.004$ respectively). The highest values of SST and SSS throughout the year were found in the southernmost section of the study region. Moreover, the average seasonal variation of $f \mathrm{CO}_{2, \mathrm{sw}}$ and $\mathrm{pH}_{\mathrm{T}}$ in the Canary waters $\left(42.12 \pm 0.07 \mu \mathrm{atm}\right.$ and $0.0^{\wedge n} \pm 9.001$ units, respectively) turned out to be slightly lower than those obtained in th $: \mathrm{m}$ rthwest African coastal waters $(50.39 \pm 1.13 \mu \mathrm{atm}$ and $0.048 \pm 0.001$ units, respectivaly) Supplementary Figures A.1, A.2 and A.3 show the temporal and spatial distribution of thu studied variables on each route. The $\mathrm{C}_{\mathrm{T}}$ was normalized $\left(\mathrm{NC}_{\mathrm{T}}\right)$ to a constant SSS of $\langle 6]$ (the annual average SSS for the entire region) to remove the effect of evaporat $\urcorner n$ and precipitation. Similarly, the $\mathrm{pH}_{\mathrm{T}}$ values were normalized to a constant temperatur of $21.0{ }^{\circ} \mathrm{C}\left(\mathrm{pH}_{\mathrm{T}, 21}\right)$ to remove the temperature dependence on the variation of $\mathrm{r}^{-1}{ }_{\mathrm{T}}$ ' ' antana-Casiano et al., 2001; González-Dávila et al., 2003). The $f \mathrm{CO}_{2, \mathrm{sw}}$ was normai zed io the average SST of each route to study the thermal and non-thermal effect in their $\mathrm{sp}_{\mathrm{u}^{+}}{ }_{\mathrm{A}} \mathrm{l}$ and temporal distribution, as indicated in section 2.2.

\subsection{Inter-island rous $\mathrm{s}$}

From February 2019 to February 2020, 23 inter-island routes were completed between Gran Canaria and Tenerife (GC-TNF, $\left.15.4^{\circ} \mathrm{W}-16.2^{\circ} \mathrm{W}\right), 17$ between Tenerife and Lanzarote (TNFLNZ, $16.2^{\circ} \mathrm{W}-13.5^{\circ} \mathrm{W}$ ) and 2 between Gran Canaria and Lanzarote (GC-LNZ, $15.4^{\circ} \mathrm{W}$ $\left.13.5^{\circ} \mathrm{W}\right)$; the latter were included with the TNF-LNZ route. The inter-island routes followed a latitudinal transect between $28.1^{\circ} \mathrm{N}$ and $29.0^{\circ} \mathrm{N}$. The results showed temporal and longitudinal variation and were annually and seasonally averaged every $0.05^{\circ}$ and $0.1^{\circ}$ longitude on the GC-TNF and TNF-LNZ routes, respectively (Fig. 2). 
The seasonal trends of $\mathrm{CO}_{2}$ system parameters and fluxes both on the GC-TNF and the TNFLNZ routes were similar and coincided with previous studies at ESTOC (González-Dávila et al., 2003; González-Dávila et al., 2010; Santana-Casiano et al., 2007). The maximum average seasonal variation (winter to summer values) of $f \mathrm{CO}_{2, \mathrm{sw}}$ and $\mathrm{FCO}_{2}$ were $42.15 \pm 0.10 \mu \mathrm{atm}$ and $5.56 \pm 0.01 \mathrm{mmol} \mathrm{m}^{-2} \mathrm{~d}^{-1}$, respectively, on the GC-TNF route and $42.09 \pm 0.02 \mu \mathrm{atm}$ and $5.00 \pm 0.03 \mathrm{mmol} \mathrm{m}^{-2} \mathrm{~d}^{-1}$, respectively, on the TNF-LNZ route. The seasonality of $\mathrm{pH}_{\mathrm{T}}$ was linked to changes in $f \mathrm{CO}_{2, \mathrm{sw}}$ and $\mathrm{FCO}_{2}$, with inverse seasonal trends of $f \mathrm{CO}_{2, \mathrm{sw}}$ and $\mathrm{pH}_{\mathrm{T}}$ throughout the longitudinal transects. The maximum average *arıtion of $\mathrm{pH}_{\mathrm{T}}$ was $0.040 \pm$ 0.001 units for both routes between winter and summe.. .'owever, once the temperature dependence was removed, the maximum average rar.tion of $\mathrm{pH}_{\mathrm{T}, 21}$ occurred between

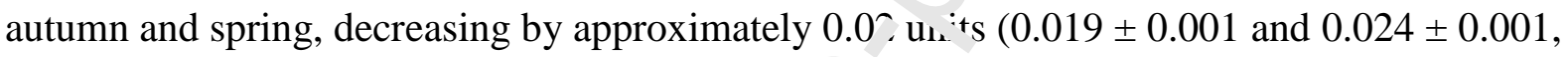
respectively). The maximum variation range $i_{1}-m$ was similar for both routes $(13.14 \pm 0.22$ and $14.18 \pm 0.32 \mu \mathrm{mol} \mathrm{kg}^{-1}$ ) and too. $\mathrm{r}$ ace between cold and warm months. Seasonal changes showed longitudinal difference on both the GC-TNF and the TNF-LNZ routes. The system behaved as a source of $\mathrm{CC}_{-}$in the warm months (June-November) and as a sink in the cold months (December-May), coinciding with maximum and minimum values of $f \mathrm{CO}_{2, \mathrm{sw}}$, respectively (Table 1).

\subsubsection{Gran Cana: : 1 - enerife route (GC-TNF)}

The seasonal variability of the variables along the GC-TNF route presented longitudinal differences between the westernmost area and the easternmost region, particularly in the warm months (Fig. 2). The seasonal averages of $f \mathrm{CO}_{2, \mathrm{sw}}$ and $\mathrm{FCO}_{2}$ were higher in the westernmost section of the route $\left(15.95-16.20^{\circ} \mathrm{W}\right)$ in autumn $(408.33 \pm 0.79 \mu \mathrm{atm}$ and $1.16 \pm$ $\left.0.15 \mathrm{mmol} \mathrm{m} \mathrm{m}^{-1}\right)$, coinciding with the maximum registered temperatures $\left(22.22 \pm 0.03{ }^{\circ} \mathrm{C}\right)$ (Fig. 2 and Fig. A.1). The maximum autumn average values of $f \mathrm{CO}_{2, \mathrm{sw}}$ and $\mathrm{FCO}_{2}$ at $16.025^{\circ} \mathrm{W}$ were $410.45 \pm 0.72 \mu \mathrm{atm}$ and $1.92 \pm 0.14 \mathrm{mmol} \mathrm{m}^{-2} \mathrm{~d}^{-1}$, respectively, decreasing 
eastwardly to $399.52 \pm 0.60 \mu$ atm and $-0.85 \pm 0.13 \mathrm{mmol} \mathrm{m}^{-2} \mathrm{~d}^{-1}$, respectively, at $15.925^{\circ} \mathrm{W}$. This change in behaviour from source to sink within only $0.1^{\circ}$ longitude can be explained by the location of this part of the route in a leeward area of the Anaga mountains, on the east coast of Tenerife.

In order to understand longitudinal differences, two stations were selected along the GC-TNF route: the first positioned in a coastal influenced area $\left(16.05 \pm 0.1^{\circ} \mathrm{W}\right)$ and the second in an open-ocean region $\left(15.7 \pm 0.1^{\circ} \mathrm{W}\right)$, in which $\mathrm{FCO}_{2}$ was negative (sink) during most of the year except for the summer (Fig. 3). The highest SST and SSS ralu.s throughout the year and the greatest variability of $\mathrm{FCO}_{2}$ occurred at the westernr $1 \mathrm{Os}$. station. The $\mathrm{SST}, f \mathrm{CO}_{2, \mathrm{sw}}$ and $\mathrm{FCO}_{2}$ averages were calculated from September to Crtoier to observe autumn longitudinal differences. The westernmost station presented highe ${ }_{i}\left(\right.$ ? $_{2}$ variables $\left(23.05 \pm 0.06{ }^{\circ} \mathrm{C}, 420.46\right.$

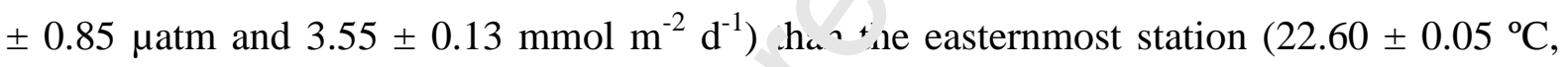
$416.89 \pm 0.59 \mu$ atm and $2.51 \pm 0.09 \mathrm{n}_{\mathrm{n}} \mathrm{nc}^{-} \mathrm{m}^{-2} \mathrm{~d}^{-1}$ ). Values of $\mathrm{pH}_{\mathrm{T}}$ and $\mathrm{pH}_{\mathrm{T}, 21}$ changed by $0.003 \pm 0.001$ and $0.004 \pm 0.001$ units, -espectively, between the stations in the same period. An average spatial $f \mathrm{CO}_{2, \mathrm{sw}}$ differer $\mathrm{r}$ ( $1.60 \pm 0.27 \mu \mathrm{atm}$ was obtained between westernmost and easternmost stations. The a asonal variation of $f \mathrm{CO}_{2, \mathrm{sw}}$ was driven by temperature, with the T/B ratio at the westerni. $\varkappa_{c}$ station being slightly higher than at the easternmost station (Table 2) due to the spa: $\because$ difference in $\Delta f \mathrm{CO}_{2, \text { temp }}(81.15$ and $69.60 \mu \mathrm{atm}$, respectively).

The $\mathrm{C}_{\mathrm{T}}$ and $\mathrm{NC}_{\mathrm{T}}$ presented a seasonal trend at both stations (Fig. 3), with the lowest annual average $\mathrm{NC}_{\mathrm{T}}\left(2102.97 \pm 1.30 \mu \mathrm{mol} \mathrm{kg}{ }^{-1}\right)$ located at the westernmost station with higher salinity values $(36.788 \pm 0.022)$. The trends show that the decrease in $\mathrm{C}_{\mathrm{T}}$ and $\mathrm{NC}_{\mathrm{T}}$ values took place on both inter-island routes between February-March and September-October, when MLD decreased and stratification increased due to surface warming (Santana-Casiano et al., 2007). As a result, vertical mixing of deep waters decreased. Between September and October, low SSS values $(<36.5)$ were measured at $15.7 \pm 0.1^{\circ} \mathrm{W}$, coinciding with slightly 
lower values of SST and $\mathrm{C}_{\mathrm{T}}\left(22.60 \pm 0.05{ }^{\circ} \mathrm{C}\right.$ and $2098.17 \pm 1.88 \mu \mathrm{mol} \mathrm{kg}{ }^{-1}$, respectively $)$ compared to the station $16.05 \pm 0.1^{\circ} \mathrm{W} \quad\left(23.05 \pm 0.06\right.$ and $2100.86 \pm 1.04 \mu \mathrm{mol} \mathrm{kg}{ }^{-1}$, respectively). This suggests that a cold and low salinity filament could be passing through this station during this period of the year and that the $\mathrm{C}_{\mathrm{T}}$ would be depleted at the surface due to the increase in biological uptake.

\subsubsection{Tenerife-Lanzarote (TNF-LNZ)}

Longitudinal variations were observed on the TNF-LNZ route, especially during summer and autumn. The $f \mathrm{CO}_{2, \mathrm{sw}}$ and $\mathrm{FCO}_{2}$ during summer were higher at $\sim \mathrm{n}_{\mathbf{1}}$-ximately $16.0^{\circ} \mathrm{W}(426.77$ $\pm 0.83 \mu \mathrm{atm}$ and $\left.2.51 \pm 0.08 \mathrm{mmol} \mathrm{m} \mathrm{d}^{-1}\right)$, coinciding wi $\mathrm{n}$ li e maximum SST $(22.93 \pm 0.05$

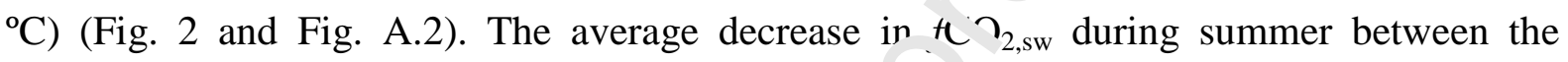

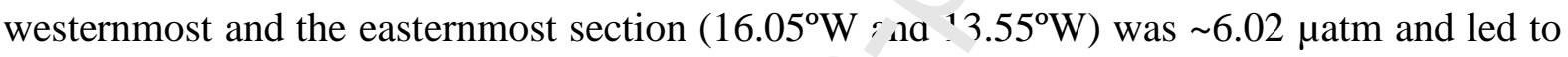
an increase in $\mathrm{pH}_{\mathrm{T}}$ and $\mathrm{pH}_{\mathrm{T}, 21}$ of $0.006 \pm 0 .\left(\partial_{1}\right.$ ar $\mathrm{d} 0.011 \pm 0.001$ units, respectively. The $f \mathrm{CO}_{2, \mathrm{sw}}$ and $\mathrm{FCO}_{2}$ in the easternmost $\mathrm{sec}^{-} \mathrm{i} \%$ of the route increased during autumn within the channel between Lanzarote and Fuertev ntura and in coastal waters to the south of Lanzarote. During autumn, the surface water $\mathrm{ch}^{`}$ ged from being a $\mathrm{CO}_{2}$ sink to being a powerful $\mathrm{CO}_{2}$ source similar to what was obs rvec during summer in the same location, with an increase in $\mathrm{FCO}_{2}$ from $-0.64 \pm 0.10$ tr $2 . .^{-7} \pm 0.15 \mathrm{mmol} \mathrm{m} \mathrm{m}^{-2}$ between $14.15^{\circ} \mathrm{W}$ and $13.55^{\circ} \mathrm{W}$. SST and SSS were relatively co. tant in the westernmost part of the route and decreased eastwardly during all seasons. The maximum variations of SST and SSS $\left(-0.52 \pm 0.02{ }^{\circ} \mathrm{C}\right.$ and $-0.11 \pm$ 0.03, respectively) with respect to the average $\left(20.99 \pm 0.05{ }^{\circ} \mathrm{C}\right.$ and $36.75 \pm 0.06$, respectively) were observed in the easternmost section around the channel between Lanzarote and Fuerteventura, in a region close to the African continental shelf and influenced by filament incursion. In the westernmost sector, protected by the eastern islands from filament incursions (Davenport et al., 1999), the maximum variations of SST and SSS were $0.5 \pm 0.02$ ${ }^{\circ} \mathrm{C}$ and $0.07 \pm 0.04$, respectively. 
Four stations along the TNF-LNZ route $\left(15.6 \pm 0.1^{\circ} \mathrm{W}, 15.0 \pm 0.1^{\circ} \mathrm{W}, 14.5 \pm 0.1^{\circ} \mathrm{W}\right.$ and 13.9 $\pm 0.1^{\circ} \mathrm{W}$ ) were selected (Fig. 4). The results obtained for the three westernmost stations with the lowest coastal influence were similar to those obtained on the GC-TNF route. At $13.9 \pm$ $0.1^{\circ} \mathrm{W}$, in a shallower region within the Lanzarote and Fuerteventura channel, annual average of SST $\left(20.57 \pm 0.10{ }^{\circ} \mathrm{C}\right)$ and $\operatorname{SSS}(36.652 \pm 0.023)$ were lower $\left(0.33-0.53{ }^{\circ} \mathrm{C}\right.$ and 0.109 0.140) than at the other stations due to the decrease of the bottom depth and its greater exposure to cold and less salinity water filaments. The highest seasonal $\mathrm{FCO}_{2}$ variability was observed at the easternmost station, with maximum outgassin fro. $_{2}$ June to October $(2.53 \pm$ $0.15 \mathrm{mmol} \mathrm{m} \mathrm{m}^{-2}$ ). Seasonal variability of $f \mathrm{CO}_{2, \mathrm{sw}}$ was $\mathrm{m} \_\mathrm{n} \mathrm{\lrcorner}$, driven by thermal effects at all the stations. The T/B ratios (Table 2) show that te $e_{1}$ 'nerature control dominated over biological activity at the westernmost stations. The $\mathrm{s}$ zas nal variability of $\mathrm{pH}_{\mathrm{T}}$ was driven by the change in $f \mathrm{CO}_{2, \mathrm{sw}}$ and was also greater at th w esternmost and easternmost point. When the temperature dependence on $\mathrm{pH}_{\mathrm{T}} \mathrm{W}_{\boldsymbol{c}} \mathrm{r}_{\text {- }}$ moved, the maximum variability of $\mathrm{pH}_{\mathrm{T}, 21}$ was observed at stations $15.0 \pm 0.1^{\circ} \mathrm{W}$ and $: 4.5 \pm 0.1^{\circ} \mathrm{W}$. Values of $\mathrm{pH}_{\mathrm{T}, 21}$ were higher at $15.6 \pm$ $0.1^{\circ} \mathrm{W}$ during the cold months, $\cdots$ hi. minimum values were registered at $13.9 \pm 0.1^{\circ} \mathrm{W}$ throughout the year.

The $\mathrm{C}_{\mathrm{T}}$ variation (Fig. 4) $\mathrm{v}_{\mathrm{a}} \cdot$. milar at all stations and coincided with that observed on the GC-TNF route (Fig. 3). 7 ne $\mathrm{NC}_{\mathrm{T}}$ change ranged between $\sim 2090$ and $\sim 2015 \mu \mathrm{mol} \mathrm{kg}^{-1}$ at all stations except for the stations located within the channel between Lanzarote and Fuerteventura, where $\mathrm{NC}_{\mathrm{T}}$ ranged between $\sim 2105$ and $\sim 2120 \mu \mathrm{mol} \mathrm{kg}{ }^{-1}$, due to a higher mixing with deep rich $\mathrm{CO}_{2}$ water.

\subsection{Canary Islands-Strait of Gibraltar route (CI-SG)}

27 transects were completed between the Canary Islands and the entry of the Strait of Gibraltar $\left(\sim 28.1-35.8^{\circ} \mathrm{N}\right)$. These transects were used to study the seasonal and spatial variability of the $\mathrm{CO}_{2}$ system and air-sea exchange in transitional waters between the 
northwest African coastal upwelling and the oligotrophic open-ocean waters of the North Atlantic subtropical gyre. The usual route of the vessel runs at an approximate distance of 2$4^{\circ}$ of longitude from the African coastline at its furthest point around the Bay of Agadir and Cape Ghir latitude $\left(\sim 30.6^{\circ} \mathrm{N}\right)$ and between 0.5 and $1.5^{\circ}$ of longitude at its closest point around the Cape Beddouza latitude $\left(\sim 32.5^{\circ} \mathrm{N}\right)$. Only during April 2019 , the vessel was close to the African coastline $\left(\sim 0.5^{\circ}\right.$ of longitude) along the area of maximum upwelling between Cape Ghir and Beddouza.

The temporal and latitudinal distribution of the results (Fig. A 2) s:ows a seasonality similar to that observed in the Canary basin (Fig. A.1 and Fig. A.2), with $f \mathrm{CO}_{2, \mathrm{sw}}$ values directly proportional $\left(\mathrm{R}^{2}>0.76\right)$ to the measured SST. Annיaı and seasonal average every $0.25^{\circ}$ latitude (Fig. 5) showed that temperature drives $f \mathrm{CC}_{2}$,sw and $\mathrm{FCO}_{2}$ variations. The maximum and minimum $f \mathrm{CO}_{2, \mathrm{sw}}$ and $\mathrm{FCO}_{2}$ values were $\mathrm{b}_{\llcorner}$ar ed during summer (June-September) and winter (December-March), respective, $\epsilon^{-}$. These values presented a strong latitudinal variability during all the seasons along the northwest African coastline. The average $f \mathrm{CO}_{2, \mathrm{sw}}$ and $\mathrm{pH}_{\mathrm{T}}$ presented a maximum $1^{\mathrm{r}^{+} \mathrm{itu}}{ }^{\mathrm{N}}{ }^{\mathrm{i}}$ al variation during summer $(43.15 \pm 1.92 \mu \mathrm{atm}$ and $0.036 \pm 0.002$ units, respective'v), which was three times greater than the annual average of maximum latitudinal variatio: $\Upsilon_{1} 3.14 \pm 1.78 \mu$ atm and $0.011 \pm 0.001$ units, respectively).

Minimum summer ave ${ }^{\prime} \mathrm{ge}_{\mathrm{e}} \mathrm{SST}$, SSS, $f \mathrm{CO}_{2, \mathrm{sw}}$ and $\mathrm{FCO}_{2}$ and maximum summer $\mathrm{pH}_{\mathrm{T}}$ were observed at the Cape Ghir latitude (Fig. 5), between the area of greatest intensity of the coastal upwelling to the north and the concave part of the coastline near the Canary archipelago, where the wind direction is locally modified and the upwelling is less intense.

Two anomalous events occurred on April 6 and December 14, 2019 (Fig. A.3): minimum and maximum values of $f \mathrm{CO}_{2, \mathrm{sw}}$, were respectively determined. At the same time, minimum SST were recorded in the section between Cape $\operatorname{Sim}\left(\sim 31.4^{\circ} \mathrm{N}\right)$ and Beddouza $\left(\sim 32.5^{\circ} \mathrm{N}\right)$, possibly related to cold water upwelling. The minimum $f \mathrm{CO}_{2, \mathrm{sw}}$ on April 6, 2019 could indicate that 
biological absorption reduced the $\mathrm{CO}_{2}$ excess in cold upwelled waters, while the maximum in December suggests that biological activity at this time of the year was not enough to reduce the $\mathrm{CO}_{2}$ excess.

Five stations were selected along the northwest African coast. The station at $29.8 \pm 0.2^{\circ} \mathrm{N}$ (Fig. 6) is located near the Bay of Agadir, south of Cape Ghir, an area protected from strong north-easterly winds by the Atlas Mountains (Mittelstaedt, 1991). The stations at $30.7 \pm$ $0.2^{\circ} \mathrm{N}$ (Fig. 6) and $31.2 \pm 0.2^{\circ} \mathrm{N}$ (Fig. A.4) were located between Cape Ghir and Cape Sim

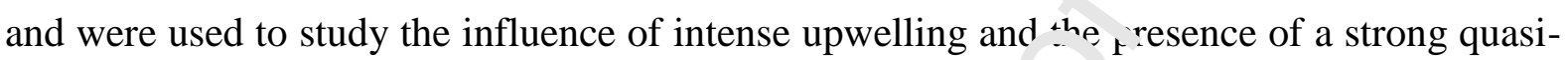
permanent filament on the $\mathrm{CO}_{2}$ system and air-sea exch ag $_{\iota}$ at the longitude visited by the vessel. Finally, the stations at $33.0 \pm 0.2^{\circ} \mathrm{N}$ (Fig. 6) and $\jmath^{1} 2 \pm 0.2^{\circ} \mathrm{N}$ (Fig. A.4) were located north of Cape Beddouza to compare the different in Au nce of upwelling on the $\mathrm{CO}_{2}$ system along the northwest African coast. Due $t$, ne longitudinal variability of the routes, westernmost and easternmost longitudiı.1 itervals were represented separately to study the open-ocean and coastal waters, respect, ely.

The seasonal variation range of $f r \mathrm{O}_{2, \mathrm{~s}}, \mathrm{pH}_{\mathrm{T}}$ and $\mathrm{pH}_{\mathrm{T}, 21}$ were maximum to the north of Cape Beddouza $(78.19 \pm 0.24 \mu \mathrm{atm}\urcorner .074 \pm$,0.001 and $0.046 \pm 0.001$ units, at station $\left.33.0 \pm 0.2^{\circ} \mathrm{N}\right)$ and minimum around Cane $\mathcal{C h}_{\mathbf{h}}(49.47 \pm 0.03 \mu \mathrm{atm}, 0.048 \pm 0.001$ and $0.044 \pm 0.001$ units at station $30.7 \pm 0.2^{\circ} \mathrm{N}$, cornciding with the maximum and minimum seasonal SST variation $\left(6.43 \pm 0.01\right.$ and $5.10 \pm 0.05{ }^{\circ} \mathrm{C}$ at the respective stations). In the Bay of Agadir (Fig. 6), the SST, $f \mathrm{CO}_{2, \mathrm{sw}}$ and $\mathrm{pH}_{\mathrm{T}}$ range was intermediate between those observed at the previous stations. The latitudinal difference was especially high during summer and autumn (Fig. 5) due to a spatial change in SST of $\sim 3^{\circ} \mathrm{C}$ (between $\sim 20$ and $\sim 23^{\circ} \mathrm{C}$ ) throughout the latitudinal range, with maximum $f \mathrm{CO}_{2, \mathrm{sw}}$ and minimum $\mathrm{pH}_{\mathrm{T}}$ around $420 \mu$ atm and 8.03 units, respectively, at the southernmost stations and $450 \mu \mathrm{atm}$ and 8.01-8.02 units, respectively, at the northernmost stations (Fig. 5 and Fig. A.4). During winter and spring, the spatial change 
in SST was slightly lower $\left(\sim 2{ }^{\circ} \mathrm{C}\right.$, between $\sim 17$ and $\left.\sim 19^{\circ} \mathrm{C}\right)$ and the $f \mathrm{CO}_{2, \mathrm{sw}}$ and $\mathrm{pH}_{\mathrm{T}}$ were practically constant at all stations (360-370 $\mu$ atm and 8.08-8.09 units). The strongest sink was observed in the cold period between the Canary Islands and Cape Beddouza, where the range of variation of $\mathrm{FCO}_{2}$ was maximum (between $\sim-3.66$ and $\sim 1.46 \mathrm{mmol} \mathrm{m}^{-2} \mathrm{~d}^{-1}$ south of Cape Beddouza and between $\sim-2.35$ and $\sim 1.67 \mathrm{mmol} \mathrm{m}^{-2} \mathrm{~d}^{-1}$ north of Cape Beddouza).

The T/B ratios (Table 2) show that the $f \mathrm{CO}_{2, \mathrm{sw}}$ variations were driven by thermal processes at all stations. The thermal effect on the seasonality of $f \mathrm{CO}_{2, \mathrm{sw}}$ was strongest north of Cape Beddouza towards more temperate regions, where the coasta ${ }^{1}$ י p $_{v}$ elling loses intensity and biological activity is reduced. The lowest values (Table 2 w 'e in Cape Ghir latitude, where the intensity of upwelling and phytoplankton blooms was highest. These differences derived from the change in the intensity of upwelling have lsu heen reflected in the variation of $\mathrm{C}_{\mathrm{T}}$ (Fig. A.5) which was maximum at $30.7 \pm 0.2^{\circ} \mathrm{N}$. $n r^{\prime} 31.2 \pm 0.2^{\circ} \mathrm{N}$, where the seasonal change in SSS (Fig. A.5) is greater due to th $d$ ffferent intensity of the upwelling and offshore transport throughout the year. Once the salinity effect was removed, $\mathrm{NC}_{\mathrm{T}}$ (Fig. A.5) decreased between February and $\mathrm{n}_{\mathrm{C}}{ }^{\mathfrak{}}$,er derived from the increase in biological uptake at this time of the year. Moreove $\mathrm{r}_{\mathrm{N}} \mathrm{NC}_{\mathrm{T}}$ increases in the cold months due to both vertical mixing and the strong $\mathrm{CO}_{2}$ sink at thi- ${ }^{+}$. me of year caused by the low SST recorded in the upwelling. At the rest of the statio. - me variability of $\mathrm{C}_{\mathrm{T}}$ and $\mathrm{NC}_{\mathrm{T}}$ was lower and encompassed similar ranges to those observed on the inter-island routes, which reflects the lower influence of upwelling at these stations.

Longitudinal differences were observed between coastal and oceanic waters. The T/B ratio (Table 2) was higher in Cape Sim and Beddouza $\left(31.2 \pm 0.2^{\circ} \mathrm{N}\right.$ and $33.0 \pm 0.2^{\circ} \mathrm{N}$, respectively), which may be related to the greater amplitude of seasonal variation in SST observed compared to the open-ocean zone.

\section{Discussion}




\subsection{Seasonal variability of $f \mathrm{CO}_{2, \mathrm{sw}}$ and $\mathrm{pH}_{\mathrm{T}}$}

The seasonal variability of $f \mathrm{CO}_{2, \mathrm{sw}}$ and $\mathrm{FCO}_{2}$ values was driven by seasonal variations of SST, where the system behaved as a source in the warm months and as a sink in the cold months. This agrees with previous studies at the ESTOC site (González-Dávila et al., 2003; González-Dávila et al., 2010; Santana-Casiano et al., 2001; Santana-Casiano et al., 2007). The greatest increase in $f \mathrm{CO}_{2, \mathrm{sw}}$ occurred between winter and summer and followed a linear trend with temperature (Fig. A.6), with a linear regression slope of $12.27 \mu$ atm ${ }^{\circ} \mathrm{C}^{-1}$ for the GC-TNF route, $11.41 \mu$ atm ${ }^{\circ} \mathrm{C}^{-1}$ for the TNF-LNZ route and ${ }^{11.1 .} \mu$ atm ${ }^{\circ} \mathrm{C}^{-1}$ for the CI-SG route. The theoretically $f \mathrm{CO}_{2, \mathrm{sw}}-\mathrm{SST}$ relationship of $10 . \mathrm{J} \pm 1.1 \mu \mathrm{atm}{ }^{\circ} \mathrm{C}^{-1}$ was reduced between February and October $\left(10.35,9.81\right.$ and $1(1) .9 \mu$ atm ${ }^{\circ} \mathrm{C}^{-1}$, respectively) as a consequence of the decrease in $C_{T}$ due to biologica* $a_{1}$ 'wdown. These results were slightly lower than those obtained between March ar $d$ Ir.ober for the ESTOC site $(12.12 \pm 0.48$ $\mu$ atm ${ }^{\circ} \mathrm{C}^{-1}$; González-Dávila et al., 2003, T.e seasonal variation of $f \mathrm{CO}_{2, \mathrm{sw}}$ led to a decrease in $\mathrm{pH}_{\mathrm{T}}$ of 0.0009 units $\mu_{\mathrm{atm}}^{-1}$ through ${ }_{\mathrm{L}}$ ut the region between winter and summer, with an average variation range from $8.0^{77} \pm\ulcorner .007$ to $8.037 \pm 0.001$ units in the Canary basin and from $8.084 \pm 0.002$ to $8.0 \div 5 \pm 0.002$ units along the African coastline. The linear relationships between SST $\mathrm{N}^{\mathrm{C}, \mathrm{sw}}$ and $\mathrm{pH}_{\mathrm{T}}$ at this time are presented in Table 3.

The T/B values (Tabı $\angle$ ) indicate that the temperature effect on the $\mathrm{CO}_{2}$ solubility in seawater controls air-sea exchange fluxes over biological uptake and other non-thermal processes. The contribution of the thermal processes in the variation of $f \mathrm{CO}_{2, \mathrm{sw}}$ was double the contribution of the biological activity at all the selected stations, with minimum T/B values higher than 1.60. Lowest values were obtained in the areas most influenced by the influx of nutrients and phytoplankton blooms, between Cape Sim and Cape Ghir, and with greater mesoscale variability south of Cape Ghir and at certain stations of the Canary archipelago. 


\subsection{Spatial variability of the $\mathrm{CO}_{2}$ system parameters and fluxes}

The differences observed in the seasonal variation for each carbon variable in the Canary basin and along the northwest African coastline are related to the hydrographic characteristics of each zone, to the intensity of the African coastal upwelling and to the mesoscale variability associated with offshore transport by filaments and eddies. The inter-island routes (GC-TNFLNZ) presented differences between the oceanic and coastal waters. Seasonal variation of the $\mathrm{CO}_{2}$ system and air-sea exchange were similar at $15.7 \pm 0.1^{\circ} \mathrm{W}(\mathrm{GC}-\mathrm{TNF}), 15.6 \pm 0.1^{\circ} \mathrm{W}$, $15.0 \pm 0.1^{\circ} \mathrm{W}$ and $14.5 \pm 0.1^{\circ} \mathrm{W}$ (TNF-LNZ) (Fig. 3 and Fig. 1) r.ese stations were located in an open-ocean area directly exposed to the Canary $\mathrm{Cu}^{\text {relı }}$ and trade winds and protected from the filament incursion by the easternmost isla. $\mathrm{A}_{\mathbf{s}} \mathrm{s}$, Lanzarote and Fuerteventura (Davenport et al., 1999). However, the greatest FCL variations occurred at the coastal

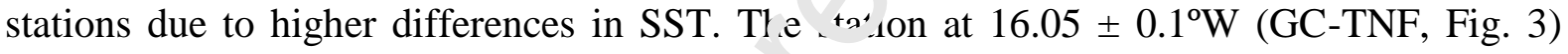
leeward of Tenerife presented higher ave At the station located within the Lan`'rote-Fuerteventura channel $\left(13.9 \pm 0.1^{\circ} \mathrm{W}\right.$, Fig. 4$)$, frequently influenced by coasta' ip w/lling of cold-water and high-productivity filament incursion, the average SST an. SSs were lower than in western waters throughout the year. A west to east decrease in $\mathrm{f}_{\mathrm{C}}$,sw seasonal variability was observed in Canary Islands waters and in the T/B ratio on $:$ un inter-island routes. This shows that the thermal effect on $f \mathrm{CO}_{2, \mathrm{sw}}$ variability was greater in the westernmost section of each route, although clearly dominating in the entire Canary Islands subregion. The spatial variability was due to the recirculation of coastal upwelling in the Canary basin (Johnson and Stevens, 2000; Mittelstaedt, 1991; Pelegrí et al., 2005). The Canary Current diverges from the coast to the south of Cape Ghir and flows through the Canary archipelago. The majority of the flux travels between the eastern island channels, Gran Canaria-Fuerteventura and Fuerteventura-African coast (Hernández-Guerra et al., 2002; Knoll et al., 2002). This lead to the maximum $\mathrm{CO}_{2}$ sink of the inter-island routes 
observed at the easternmost stations of the TNF-LNZ route (between $-0.32 \pm 0.05$ and $-0.36 \pm$ $0.04 \mathrm{~mol} \mathrm{~m}^{-2} \mathrm{yr}^{-1}$, Fig. 4). The interaction between the Canary Current with the Cape Ghir filament, which extends beyond $15^{\circ} \mathrm{W}$, forms cyclonic eddies which move southward, passing through the Canary Islands (Mittelstaedt, 1991). The recirculation results in the low SST and SSS signals observed between Gran Canaria and Tenerife from September to October, when the Cape Ghir filament was strongest. Evidence of upwelling has been observed on the west coast of Gran Canaria (Johnson and Stevens, 2000). This upwelling could produce the low T/B ratio (1.60) at the station located to the -orthwest of Gran Canaria $\left(15.7 \pm 0.1^{\circ} \mathrm{W} ; \mathrm{GC}-\mathrm{TNF}\right)$.

The seasonal variation of the results along the continenta - helf of northwest Africa presented an important latitudinal variation (Borges et al., 200₹; L i et al., 2006) related to the increase in the seasonal SST gradient towards higher litiı.drs from the Canary Islands to the Strait of Gibraltar. Regional differences in seaw te properties along the African coastal transition zone are driven by the north-easterly rinds and by the intensity of the permanent coastal upwelling between Cape Blanc $a^{\text {nd }}$ t.` Gulf of Cadiz. The mesoscale features were mainly generated by thermohaline ho. izoncal gradients and by the dynamic character of the front from the coastal upwellino (Dr.stor et al., 2008; Pérez-Rodríguez et al., 2001; Zenk et al., 1991). These mesoscan teatures interacted with other mesoscale features, such as coastal cyclonic and anticyclonic eddies (Benítez-Barrios et al., 2011; Ruiz et al., 2014) which propagate westward as Rossby waves (Mason et al., 2011; Sangrà et al., 2009). These features promote the transport of the characteristics of the upwelling towards the open ocean in this Northeast Atlantic region (Valdés and Déniz-González, 2015).

The lowest SST, $f \mathrm{CO}_{2, \mathrm{sw}}, \mathrm{FCO}_{2}$ and $\mathrm{pH}_{\mathrm{T}}$ seasonal variability occurred at latitudes $30.7 \pm$ $0.2^{\circ} \mathrm{N}$ (Fig. 6) and $31.2 \pm 0.2^{\circ} \mathrm{N}$ (Fig. A.4) between Cape Ghir and Cape Beddouza. This region is characterised by a permanent and intense upwelling and offshore transport by 
filaments, especially during summer (Johnson and Stevens, 2000; Mittelstaedt, 1991; Pelegrí et al.,2005). Near Cape Ghir $\left(\sim 30.6^{\circ} \mathrm{N}\right)$, a quasi-permanent surface filament is formed which stretches over 100 kilometres in open ocean (Hagen et al., 1996; Pelegrí et al., 2005) and is associated with the formation of cyclonic eddies to the south which are transported offshore (Johnson and Stevens, 2000). A detailed study of the Northwest African upwelling area provided by Mittelstaedt (1991) shows that upwelling is less intense throughout the year to the North of Cape Beddouza due to the concave shape of the Moroccan coastline to the Strait of Gibraltar and its unfavourable orientation against the equ+or vard blowing trades. It is more intense throughout the year between Cape Ghir and st'douza, where the coastline has a convex shape and is more exposed to trade winds ana the Canary Current. This explains that the annual and summer average of SST and $\mathrm{S}^{\odot} \mathrm{S}_{1}$, rth of $33.0^{\circ} \mathrm{N}$ were higher than the values obtained at the Cape Ghir latitude. Thi h $\mathbf{a}^{2}$ decrease in upwelling intensity caused a spatial variation of the $\mathrm{CO}_{2}$ system and ir sea fluxes to the north of Cape Beddouza, where maximum annual and summer average of $f \mathrm{CO}_{2, \mathrm{sw}}$ and $\mathrm{FCO}_{2}$ and minimum summer average of $\mathrm{pH}_{\mathrm{T}}$ were observed.

The intensity of the upwelling in tnis region would also explain the fact that the minimum values of the T/B ratio alnng $h$ African coastline were obtained at the stations of the greatest nutrient inflow and bic'ngical activity. The maximum T/B ratios (Table 2) were recorded north of Cape Beddouza, where the upwelling is less intense throughout the year. However, $\mathrm{FCO}_{2}$ presented greater seasonality at latitudes $30.7 \pm 0.2^{\circ} \mathrm{N}$ and $31.2 \pm 0.2^{\circ} \mathrm{N}$, where the $\mathrm{CO}_{2}$ sink expressed per unit area $\left(-0.71 \pm 0.04\right.$ and $-0.62 \pm 0.05 \mathrm{~mol} \mathrm{~m}^{-2} \mathrm{yr}^{-1}$, respectively) was greater than north of Cape Beddouza $\left(-0.41 \pm 0.03 \mathrm{~mol} \mathrm{~m}^{-2} \mathrm{yr}^{-1}\right.$ for $33.0 \pm 0.2^{\circ} \mathrm{N}$ and $-0.26 \pm$ $0.03 \mathrm{~mol} \mathrm{~m}^{-2} \mathrm{yr}^{-1}$ for $\left.34.2 \pm 0.2^{\circ} \mathrm{N}\right)$ and in the Bay of Agadir $\left(-0.51 \pm 0.04 \mathrm{~mol} \mathrm{~m}^{-2} \mathrm{yr}^{-1} ; 29.8 \pm\right.$ $0.2^{\circ} \mathrm{N}$ ) (Fig. 6 and Fig. A.4). Moreover, this $\mathrm{CO}_{2}$ sink was approximately twice that obtained in the Canary basin, which is less than $-0.36 \mathrm{~mol} \mathrm{~m}^{-2} \mathrm{yr}^{-1}$ at all stations. The longitudinal 
variability of the results, observable near Cape Sim and Beddouza, was related to seasonal differences in offshore transport and to the increase in SST and SSS from the coastal upwelling to open-ocean waters of $\sim 3.9^{\circ} \mathrm{C}$ and $\sim 0.2$ units, respectively, estimated by Pelegrí et al. (2005). This contrasts with the homogeneous variation of $f \mathrm{CO}_{2, \mathrm{sw}}$ in waters close to the Cape Ghir latitude (Valdés and Déniz-González, 2015).

The $f \mathrm{CO}_{2, \mathrm{sw}}$ values obtained were compared and contextualized with the $f \mathrm{CO}_{2, \mathrm{sw}}$ data collected in SOCAT for the Northeast Atlantic referenced to the year 2019. The inclusion of SOCAT data is useful to understand the longitudinal change in $f\left(C_{2, s w}\right.$ from coastal to openocean waters and to evaluate the representativeness of the sults obtained by the CanOAVOS line in a greater area in the Northeast Atlantic. Brth tata sets were studied as a function of longitude and time in the Canary archipelago (Fig. 1 7) and in the 5 latitudes of interest along the northwest African coast (Fig 7 and $f .$. , $\quad$ oCAT data show that the $f \mathrm{CO}_{2, \mathrm{sw}}$ surface longitudinal gradient is only significan $\mathrm{i}^{\mathrm{r}}$. the first $0.5-1^{\circ}$ of longitude from the African coastline in the area of maximum upwt.: ${ }^{\prime}$ ing $\left(30.7 \pm 0.2^{\circ} \mathrm{N}\right.$, Fig. $7 ; 31.2 \pm 0.2^{\circ} \mathrm{N}$, Fig. A.8) and that it decreases towards the open ${ }^{\prime} \epsilon^{\sim}$. This longitudinal gradient was clearly visible in the $f \mathrm{CO}_{2, \mathrm{sw}}$ data collected in co ${ }^{\text {tal }}$ waters around Cape Ghir in April (CanOA-VOS) and September (SOCAT). The age $f \mathrm{CO}_{2, \text { sw }}$ in April around $10.35 \pm 0.1^{\circ} \mathrm{W}(372.45 \pm 1.93$ $\mu \mathrm{atm})$ was $\sim 9.5 \mu \mathrm{atm}$ : i wer than that obtained around $11.5 \pm 0.2^{\circ} \mathrm{W}(381.97 \pm 4.22 \mu \mathrm{atm})$. This longitudinal change was more drastic in September due to the strong upwelling at this time of the year that was visible in satellite SST data and because the SOCAT data was collected closer to the coast. The low $f \mathrm{CO}_{2, \mathrm{sw}}$ values obtained near the coast from SOCAT (Fig. 7) contrast with the maximum values of the annual cycle of $f \mathrm{CO}_{2, \mathrm{sw}}$ obtained by the CanOA-VOS towards open-ocean waters during late summer (Fig 5 and A.3). The average $f \mathrm{CO}_{2, \mathrm{sw}}$ in September around $10.15 \pm 0.2^{\circ} \mathrm{W}(376.64 \pm 14.28 \mu \mathrm{atm})$ was $\sim 44$ uatm lower than that obtained around $11.55 \pm 0.25^{\circ} \mathrm{W}(420.86 \pm 8.91 \mu \mathrm{atm})$. These results show that there is a 
significant longitudinal variation of $f \mathrm{CO}_{2, \mathrm{sw}}$ that changes with seasonality towards open-ocean waters in the first $\sim 150 \mathrm{~km}$ from the Cape Ghir coastline. This longitudinal change does not appreciably affect the rest of the usual CanOA-VOS trips, which take place at a distance greater than $200 \mathrm{~km}$ from Cape Ghir. North of Cape Beddouza $\left(33.0 \pm 0.2^{\circ} \mathrm{N}\right.$ and $34.2 \pm$ $0.2^{\circ} \mathrm{N}$, Fig. A.8) and south of Cape Ghir $\left(29.8 \pm 0.2^{\circ} \mathrm{N}\right.$, Fig. A.8) the longitudinal gradient is weaker due to the decrease in the intensity of the upwelling and values were not longitudinally modified.

In the easternmost part of the Canary archipelago $\left(13-16^{\circ} \mathrm{W}\right.$, the $f \mathrm{CO}_{2}$ values of CanOAVOS line and SOCAT (Fig A.7) increased towards the whst, driven by the east to west increase of SST throughout the year (Fig 2, A. 1, and $\wedge^{\prime}<$, and in SST satellite images for the area. Data from SOOP CanOA-VOS improved the $S \mathcal{X}^{\wedge}{ }^{\mathrm{T}} \mathrm{V}$ v2020 data resolution for the area and showed the influence of mesoscale variat $\mathrm{O}_{1} . \cdots$, the spatial distribution of $f \mathrm{CO}_{2, \mathrm{sw}}$ in the eastern part of the archipelago.

The seasonality of measured $f \mathrm{CO}_{2, \mathrm{sw}}$ values and its latitudinal variation was evaluated together with the SOCAT values : $\eta$ areas of interest: the Canary archipelago $\left(27.5-29^{\circ} \mathrm{N}\right.$, Fig. A.9), Cape Ghir (30.7, Fis 7) and North of Cape Beddouza (33.0 $\pm 0.2^{\circ} \mathrm{N}$, Fig. A.9). The temporal distribution of the $\mathrm{AnOA}-\mathrm{VOS}$ and SOCAT data were fitted to the harmonic equations in Table A.L. 7 ne SOCAT data collected in September in coastal waters of Cape Ghir have been excluded from the fitting to attend to the $f \mathrm{CO}_{2, \mathrm{sw}}$ seasonality in more openocean waters (Fig. 7). The $f \mathrm{CO}_{2, \mathrm{sw}}$ seasonality obtained from the CanOA-VOS database increased towards the North and was similar to that obtained from the SOCAT data in all areas, despite the SOCAT data having a greater longitudinal dispersion towards open ocean up to $20^{\circ} \mathrm{W}$. This shows that even when there is a strong longitudinal gradient near the coast, at the location of the CanOA-VOS line the seasonality obtained was representative for a larger area in the Northeast Atlantic. 


\subsection{The relative contribution of biological activity, air-sea fluxes and horizontal transport to $\mathrm{NC}_{\mathrm{T}}$ depletion}

The temporal variation of $\mathrm{C}_{\mathrm{T}}$ was studied in detail at the stations of the inter-island routes $15.7 \pm 0.1^{\circ} \mathrm{W}(\mathrm{GC}-\mathrm{TNF})$ and $14.5 \pm 0.1^{\circ} \mathrm{W}(\mathrm{TNF}-\mathrm{LNZ})$ located to the northwest of Gran Canaria and Fuerteventura, respectively, and at all selected stations on the African continental shelf. Previous $\mathrm{CO}_{2}$ system studies in the surface ocean agree that the surface variation of $\mathrm{C}_{\mathrm{T}}$ is mainly controlled by the factors which govern salinity and other non-conservative processes (i.e. primary production, oxidation of organic matte- bıcipitation and dissolution of calcium carbonate and air-sea $\mathrm{CO}_{2}$ exchange) (e.g. Chr $\mathrm{n}$ a $\mathrm{nd}$ Pytkowicz, 1979; Lee et al., 2000; Takahashi et al., 1993; Wanninkhof and Feely, 10y?). In this study, $\mathrm{C}_{\mathrm{T}}$ was normalised to a constant salinity of 36.7 . The results allow to es $a b_{1}$. $c h$ the relative importance of the airsea exchange, the horizontal transport from th e. fr .can coastal upwelling and the biological activity in the variability of $\mathrm{NC}_{\mathrm{T}}$ betw` $\sim$ February and October. During this period, $\mathrm{NC}_{\mathrm{T}}$ decreases and the vertical mixing is $\operatorname{su}_{\mathrm{F}_{1}}$ ressed due to the decrease of the MLD, as estimated

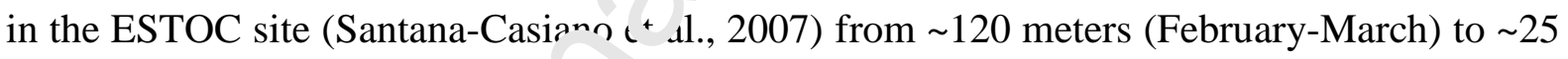
meters (September-October). i'ear the northwest African coast, the contribution of vertical diffusion, advection and ents.irment from the mixed layer due to the upwelling contributed to the $\mathrm{NC}_{\mathrm{T}}$ variability. ' ${ }^{-} \mathrm{ow}$ ever, these processes were not accounted for due to the lack of data.

The monthly changes in $\mathrm{NC}_{\mathrm{T}}$ by each of the terms in Eq. 8 were computed for the MarchJune, June-September and February-October periods (Fig. 8, Table 4). $\mathrm{NC}_{\mathrm{T}}$ decreased from March-April to September-October and increased from November to March, driven by the biological activity and vertical mixing, with maximum primary production and respiration in the respective periods. Between February and October, a net decrease in $\mathrm{NC}_{\mathrm{T}}$ was computed throughout the covered region, which was maximum at $31.2 \pm 0.2^{\circ} \mathrm{N}\left(-27.06 \mathrm{mmol} \mathrm{m}^{-3}\right)$ and 
minimum at $29.8 \pm 0.2^{\circ} \mathrm{N}\left(-8.28 \mathrm{mmol} \mathrm{m}^{-3}\right)$. The variation of $\mathrm{NC}_{\mathrm{T}}$ due to biological processes and calcification/dissolution represented $>90 \%$ of $\Delta \mathrm{NC}_{\mathrm{T}} / \mathrm{dt}$ at all stations between February and October. The effect of the air-sea exchange resulted in a net decrease in $\mathrm{NC}_{\mathrm{T}}$ of $<6 \%$. The greatest contribution of air-sea fluxes was observed at the stations located between Cape Ghir and Beddouza $\left(\sim 5.9 \%\right.$ at $30.7 \pm 0.2^{\circ} \mathrm{N}$ and $\sim 2.77 \%$ at $\left.31.2 \pm 0.2^{\circ} \mathrm{N}\right)$ and within the Canary basin $\left(\sim 2.65 \%\right.$ at point $15.7 \pm 0.1^{\circ} \mathrm{W}$ and $\sim 2.57 \%$ at point $\left.14.5 \pm 0.1^{\circ} \mathrm{W}\right)$, where the seasonal variation of $\mathrm{FCO}_{2}$ was greater. The $\mathrm{NC}_{\mathrm{T}}$ change induced by air-sea exchange was higher (between $\sim-1.07$ and $\sim-2.67 \mathrm{mmol} \mathrm{m}^{-3}$ ) during summen (Ju.e-September), coinciding with the maximum outgassing period and greater st at."cation of the water column (González-Dávila et al., 2003; Santana-Casiano et al., 3nu?).

The $\mathrm{CO}_{2}$ outgassing between June and September c sn 1 : huted between $12 \%$ and $20 \%$ in the depletion of $\mathrm{NC}_{\mathrm{T}}$ in the entire region. Howev 2 , at he northernmost station the contribution was minimal $\left(-0.67 \mathrm{mmol} \mathrm{m}^{-3} ; \sim 4.81 \%\right.$, The period between March and June presents the maximum primary production and chare in sea surface behaviour from sink to source of $\mathrm{CO}_{2}$. During these months, the ${ }^{\mathrm{r} r t}{ }^{\prime 1}$ contribution of biological activity was higher than during summer and inversely $\hat{i} \boldsymbol{r}$ the air-sea exchange. However, these $\mathrm{NC}_{\mathrm{T}}$ variation patterns presented differences betwe $n$, he stations. The lowest decrease in $\mathrm{NC}_{\mathrm{T}}$ from February to October and from Marc' to June were obtained in the most western transects around Bay of Agadir $\left(29.8 \pm 0.2^{\circ} \mathrm{N}\right)$ (Fig. 8), less influenced by coastal upwelling. At this location during spring, the air-sea exchange contributed $36.44 \%$ to the $\mathrm{NC}_{\mathrm{T}}$ depletion, while the net community production represented $64.01 \%$. The increase in the role of the air-sea exchange was due to the maximum $\mathrm{CO}_{2}$ outgassing. Moreover, during this season, the upwelling and offshore transport by filaments is less intense in the Bay of Agadir (Mittelstaedt, 1991; Pelegrí et al., 2005). Therefore, the biological activity at the Bay of Agadir reduces faster towards the open ocean than at the higher latitudes of Cape Ghir and Cape Sim. 
Differences in the contribution of the net community production were observed within the Canary basin, with a second sub-maximum in June-July. At $14.7 \pm 0.1^{\circ} \mathrm{W}$, this was even higher than the first in April-June. The second maximum during June-July may be related to the strong biological activity associated with the maximum intensity of the Cape Ghir filament, as it is transported south by the recirculation of the Canary Current through the Canary archipelago (Hernández-Guerra et al., 2002; Knoll et al., 2002).

The contribution of the advection, transport and horizontal mixing processes to the $\mathrm{NC}_{\mathrm{T}}$ depletion (Eq. 8) was calculated at the stations of the Canarr hasin, taking into account the difference in $\mathrm{NC}_{\mathrm{T}}$ and SSS with respect to the most coastri St. tion located at $30.7 \pm 0.2^{\circ} \mathrm{N}$, in Cape Ghir latitude. Along the northwest African coast $\mathrm{w}_{\mathrm{c}} \mathrm{rt}^{\mathrm{t}}$-to-east gradients were performed considering the differences in values between the mu ${ }^{+}$oceanic and coastal stations. The greatest contribution occurred at $15.7 \pm 0.1^{\circ} \mathrm{W}\left({ }^{-} \cdot \mathrm{g}\right.$ 8) as a result of the greater difference in salinity between the more saline transi: or waters of the Canary archipelago and the less saline waters of the upwelling. Betwe n February and October, the horizontal advection at this location increased $\mathrm{NC}_{\mathrm{T}}$ by $155 \cdot \mathrm{Imol} \mathrm{m} \mathrm{m}^{-3}(\sim 15 \%)$, with the highest increase during summer due to the greatest in ' nsity of the upwelling $\left(1.28 \mathrm{mmol} \mathrm{m}^{-3}, \sim 19 \%\right)$. At the other stations close to the Africa. oast, $\mathrm{NC}_{\mathrm{T}}$ and $\mathrm{SSS}$ gradients were close to zero and the horizontal transport col ' 1 vution ranged between -0.49 and $0.33 \mathrm{mmol} \mathrm{m}^{-3}$, contributing with $<3.3 \%$. These results coincide with those obtained in surface waters at the ESTOC site (González-Dávila et al., 2003) and provide a new estimation of the horizontal transport contribution of the coastal upwelling to the total $\mathrm{NC}_{\mathrm{T}}$ change.

\section{4. $\mathrm{FCO}_{2}$ in the Northeast Atlantic coastal and transition region}

The monitored routes presented annual negative values of $\mathrm{FCO}_{2}$ and behaved as a net $\mathrm{CO}_{2}$ sink. The spatial variation of $\mathrm{FCO}_{2}$ was driven by the difference between $f \mathrm{CO}_{2, \text { atm }}$ and $f \mathrm{CO}_{2, \mathrm{sw}}$ $\left(\Delta f \mathrm{CO}_{2}\right)$, since the wind speed did not present high variations between routes (Fig. 9). The 
average $\mathrm{FCO}_{2}$ calculated on the GC-TNF-LNZ routes was $-0.26 \pm 0.04 \mathrm{~mol} \mathrm{C} \mathrm{m}{ }^{-2} \mathrm{yr}^{-1}$, slightly higher than the average annual $\mathrm{FCO}_{2}$ obtained at the ESTOC site between 1996 and 2000 (-0.18 mol C m${ }^{-2}$ year ${ }^{-1}$; González-Dávila et al., 2003). The annual average $\mathrm{FCO}_{2}$ between Tenerife and Lanzarote $\left(14,500 \mathrm{~km}^{2}\right.$ covered by the VOS line) was $-0.17 \pm 0.02 \mathrm{Tg}$ $\mathrm{CO}_{2} \mathrm{yr}^{-1}\left(\mathrm{Tg}=10^{12} \mathrm{~g}\right)\left(-0.05 \pm 0.01 \mathrm{Tg} \mathrm{C} \mathrm{yr}^{-1}\right)$. The $\mathrm{CO}_{2}$ sink in the Canary basin was half of what was determined along the northwest African coast $\left(-0.48 \pm 0.09 \mathrm{~mol} \mathrm{C} \mathrm{m}^{-2} \mathrm{yr}^{-1}\right)$. For the northwest African coast covered by the VOS line from $28.9^{\circ} \mathrm{N}$ to $35.8^{\circ} \mathrm{N}\left(160,500 \mathrm{~km}^{2}\right)$, an annual average $\mathrm{FCO}_{2}$ of $-3.36 \pm 0.61 \mathrm{Tg} \mathrm{CO}_{2} \mathrm{yr}^{-1}\left(-0.92 \pm 0.17 \mathrm{Tg} \backsim \mathrm{yr}^{-1}\right)$ was computed. The average $\mathrm{FCO}_{2}$ calculated for the entire study region $\left(175, \mathrm{Cu}: \mathrm{m}^{2}\right)$ was $-0.34 \pm 0.06 \mathrm{~mol} \mathrm{C} \mathrm{m}$ ${ }^{2} \mathrm{yr}^{-1}$, which is consistent with that obtained from SOrA: data $\left(-0.37 \pm 1.11 \mathrm{~mol} \mathrm{C} \mathrm{m}^{-2} \mathrm{yr}^{-1}\right)$ for a larger area $\left(26-38^{\circ} \mathrm{N}, 5-20^{\circ} \mathrm{W}\right)$ in the Northeas $\mathrm{A}^{\prime}$ 'antic $\left(1,200,000 \mathrm{~km}^{2}\right)$. These values are lower than the carbon fluxes reported fc: $\therefore$.e Northeast Atlantic $\left(-0.6 \mathrm{~mol} \mathrm{C} \mathrm{m}^{-2} \mathrm{yr}^{-1}\right.$, Takahashi et al., 2009) and for the conti. an al shelf of the Northeast Atlantic $\left(-0.8 \mathrm{~mol} \mathrm{C} \mathrm{m}{ }^{-2}\right.$ $\mathrm{yr}^{-1}$, Chen and Borges, 2009). Howeve, these later calculations were performed with limited datasets. The average $\mathrm{FCO}_{2}$ for th- en ${ }^{+i}$ e study region was $-2.65 \pm 0.44 \mathrm{Tg} \mathrm{CO}_{2} \mathrm{yr}^{-1}(-0.72 \pm$

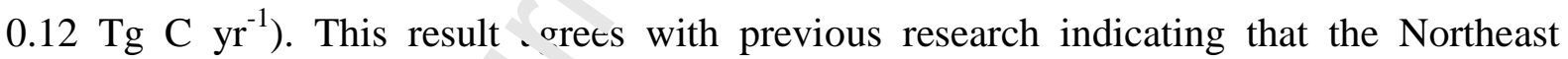
Atlantic ocean acts as an aclive $\mathrm{CO}_{2}$ sink (e.g. Khatiwala et al., 2013; Leseurre et al., 2020; Sabine et al., 2004; $1 a^{\prime}$ 'andishi et al., 2009) and with the role of continental shelves (e.g. Borges et al., 2005; Cai, 2011; Chen et al., 2013).

\section{Conclusion}

The results obtained between February 2019 and February 2020 proved the seasonal and spatial variability of the $\mathrm{CO}_{2}$ system parameters and fluxes in surface waters of the easternmost part of the Canary basin and on the northwest African continental shelf. The seasonal behaviour agrees with previous studies at the ESTOC site (González-Dávila et al., 2003; González-Dávila et al., 2010; Santana-Casiano et al., 2007), with the northwest African 
coastal upwelling system (Pelegrí et al., 2005) and with North Atlantic global surface ocean studies (Takahashi et al., 2009). The temporal and spatial change of the variables was strongly driven by temperature fluctuations with the seasons. The effect increased with latitude and presented local differences due to varying intensities of the upwelling and offshore transport along the northwest African coastline. The lowest SST and SSS were registered in the region with the greatest intensity of upwelling, between Cape Ghir and Beddouza $\left(\sim 30.6-32.5^{\circ} \mathrm{N}\right)$ (Fig. 5) and in the areas most affected by offshore transport between the eastern islands of the Canary archipelago ( 15.4-12 $5 \mathrm{~V})$ (Fig. 2). In these areas, the seasonal variation of $f \mathrm{CO}_{2, \mathrm{sw}}$ and $\mathrm{pH}_{\mathrm{T}}$ were minima' $(4 ? .47 \pm 0.03 \mu \mathrm{atm}$ and $0.048 \pm$ 0.001 units, calculated at station $30.7 \pm 0.2^{\circ} \mathrm{N}$ ) due to the 1 . w values obtained during summer. The $f \mathrm{CO}_{2, \mathrm{sw}}$ increased on the inter-island routes by ${ }^{1} 0 . \iota^{\mathrm{Q}} \pm 0.22 \mu \mathrm{atm}{ }^{\circ} \mathrm{C}^{-1}$ from February to October, which led to a $\mathrm{pH}_{\mathrm{T}}$ decrease of $\mathrm{C}^{-1}$. $\mathrm{units}^{-1} \mathrm{~atm}^{-1}$. On the northwest African continental shelf, the increase in $f \mathrm{CO}_{2, \mathrm{su}}$ ir the same period was $10.48 \pm 0.17 \mu \mathrm{atm}{ }^{\circ} \mathrm{C}^{-1}$ (a $\mathrm{pH}_{\mathrm{T}}$ decrease of 0.0009 units $\left.\mu \mathrm{atm}^{-1}\right)$. $\mathrm{NC}_{\mathrm{T}}$ seasonality was driven first by net community production and second by air-s $\sim \mathbf{v}$.hange. It was highest in the areas of maximum upwelling with higher biologic. ${ }^{1}$ activity and seasonal variation of the air-sea $\mathrm{CO}_{2}$ fluxes.

The surface waters of the en : $r$, region acted as a $\mathrm{CO}_{2}$ sink during the cold months and as a

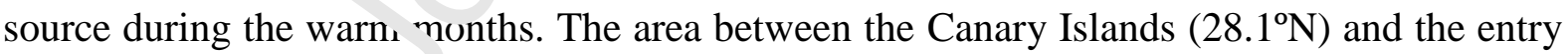
of the Strait of Gibraltar $\left(35.8^{\circ} \mathrm{N}\right)$ presented an average $\mathrm{CO}_{2}$ flux of $-2.65 \pm 0.44 \mathrm{Tg} \mathrm{CO}_{2} \mathrm{yr}^{-1}$

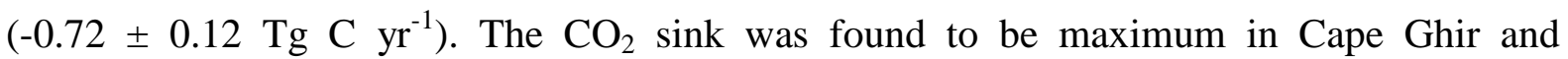
throughout the area of maximum upwelling due to minimum temperatures throughout the year which favour the solubility of $\mathrm{CO}_{2}$ in seawater. The $\mathrm{CO}_{2}$ consumption by an increased productivity in the upwelling area was counteracted by the injection of rich $\mathrm{CO}_{2}$ deep seawater, resulted in a depletion in both $\mathrm{NC}_{\mathrm{T}}$ and $f \mathrm{CO}_{2}$. The Canary archipelago, with higher annual temperatures, and the area north of Cape Beddouza, where the upwelling intensity 
declines, were weak $\mathrm{CO}_{2}$ sinks.

This study shows that high-frequency continuous monitoring of the $\mathrm{CO}_{2}$ system by VOS lines is a powerful tool to study the carbon cycle in the global surface ocean. The results expand our knowledge of air-sea $\mathrm{CO}_{2}$ exchange in the eastern boundary upwelling system of the North Atlantic subtropical gyre and highlight the importance of continuous high-temporal and spatial resolution data records. The inclusion of the CanOA-VOS line data in the SOCAT database provides a better understanding of the temporal and spatial distribution of $\mathrm{CO}_{2}$ in the surface Northeast Atlantic Ocean and appreciably increases th m m nitored area, especially in inter-island waters of the Canary archipelago and in ceralı locations along the northwest African coast where no previous data had been obtained

Acknowledgments

This study was supported by the Canary Islanc's $n$ ernment and the Loro Parque Foundation through the CanBIO project, $\mathrm{CanO}_{r}$. subproject (2019-2022) and the CARBOCAN agreement (Consejería de Transición Ecológica, Lucha contra el Cambio Climático y

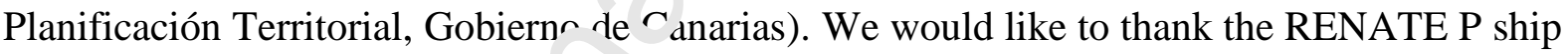
owner, the NISA-Marítima ce npany and the captains and crew members for the support during this collaboration. $\mathrm{Sp}_{\boldsymbol{c}}{ }^{-i} \mathrm{l}$ thanks to the technician Adrian Castro-Alamo for biweekly equipment maintenance anu discrete sampling of total alkalinity aboard the ship. The VOS line will be part of the Spanish contribution to the Integrated Carbon Observation System, ICOS, European Research Infrastructure starting in 2021. This study was completed while D.C.-H. was a Master student in the Oceanography and Global Change program at the Faculty of Marine Science, Universidad de Las Palmas de Gran Canaria. We thank the Surface Ocean $\mathrm{CO}_{2}$ Atlas (SOCAT), an international effort, endorsed by the International Ocean Carbon Coordination Project (IOCCP), the Surface Ocean Lower Atmosphere Study (SOLAS) and the Integrated Marine Biosphere Research (IMBeR) program, to deliver a 
uniformly quality-controlled surface ocean $\mathrm{CO}_{2}$ database. The many researchers and funding agencies responsible for the collection of data and quality control are thanked for their contributions to SOCAT.

Author contribution

All authors made significant contributions towards the writing of the manuscript. M.G.-D., J.

M. S.-C. and A.G.G. installed and maintained the equipment in the VOS line. D. C.-H. and

D. G.-S. performed the data treatments and MATLAB ${ }^{\circledR}$ routines.

\section{References}

Bates, N.R., Astor, Y.M., Church, M.J., Currie, K., Doı ?, J.E., González-Dávila, M., Lorenzoni, L., Muller-Karger, F., Olafsson, J.. anci Santana-Casiano. J.M. (2014). A time-series view of changing ocean chemistry d « and ocean acidification. 27anography, 27(1), 126-141, http://dx.doi.org/10.5670/oceanog.‘า1/..16.

Benítez-Barrios, V. M., Pelegrí, J. L., : 'ernández-Guerra, A., Lwiza, K. M. M., Gomis, D., Vélez-Belchí, P., and Hernár đę _eón, S. (2011). Three-dimensional circulation in the NW Africa coastal tran ition zone. Progress in Oceanography, 91(4), 516-533.

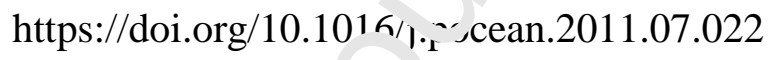

Borges, A. V., Delille, \& and Frankignoulle, M. (2005). Budgeting sinks and sources of $\mathrm{CO}_{2}$ in the coastal ocean: Diversity of ecosystem counts. Geophysical Research Letters, 32(14), 1-4. https://doi.org/10.1029/2005GL023053

de Boyer Montégut, C., Madec, G., Fischer, A.S., Lazar, A., Iudicone, D., (2004). Mixed layer depth over the global ocean: An examination of profile data and a profile-based climatology. Journal of Geophysical Research: Oceans. 109, 1-20. https://doi.org/10.1029/2004JC002378

de Boyer Montégut, C., Mignot, J., Lazar, A., Cravatte, S., (2007). Control of salinity on the 
mixed layer depth in the world ocean: 1. General description. Journal of Geophysical Research: Oceans. 112, 1-12. https://doi.org/10.1029/2006JC003953

Brainerd, K. E., and Gregg, M. C. (1995). Surface mixed and mixing layer depths. Deep-Sea Research Part I, 42(9), 1521-1543. https://doi.org/10.1016/0967-0637(95)00068-H

Cai, W. J. (2011). Estuarine and coastal ocean carbon paradox: $\mathrm{CO}_{2}$ sinks or sites of terrestrial carbon incineration? Annual Review of Marine Science, 3, 123-145. https://doi.org/10.1146/annurev-marine-120709-142723

Cai, W. J., Dai, M., and Wang, Y. (2006). Air-sea exchanm oi carbon dioxide in ocean margins: A province-based synthesis. Geophy 'ca.' Research Letters, 33(12). https://doi.org/10.1029/2006GL026219

Chen, T. A., Huang, T. H., Chen, Y. C., Bai, Y. H. X., and Kang, Y. (2013). Air-sea exchanges of coin the world's coastc1 ens. Biogeosciences, 10(10), 6509-6544. https://doi.org/10.5194/bg-10-6509 ग0`3

Chen, T. A., and Pytkowicz, R. M. (1979). On the total $\mathrm{CO}_{2}$-titration alkalinity-Oxygen system in the Pacific Ocean. ${ }^{\boldsymbol{N}} a \mathrm{t}_{\llcorner} \cdot \boldsymbol{*} \iota, 281,362-365$. https://doi.org/10.1038/281362a0

Chen, T. A., and Borges, A. V. (20u9). Reconciling opposing views on carbon cycling in the coastal ocean: Contine ${ }_{1}{ }^{29}$. shelves as sinks and near-shore ecosystems as sources of atmospheric $\mathrm{CO}_{2}$. Пеep-Sea Research Part II: Topical Studies in Oceanography, 56(810), 578-590. https://doi.org/10.1016/j.dsr2.2009.01.001

Davenport, R., Neuer, S., Hernandez-Guerra, A., Rueda, M. J., Llinas, O., Fischer, G., and Wefer, G. (1999). Seasonal and interannual pigment concentration in the Canary Islands region from CZCS data and comparison with observations from the ESTOC. International Journal of Remote Sensing, 20(7), 1419-1433. https://doi.org/10.1080/014311699212803

Dickson, A. G. (1990). Standard potential of the reaction: $\mathrm{AgCl}(\mathrm{s})+1 / 2 \mathrm{H}_{2}(\mathrm{~g})=\mathrm{Ag}(\mathrm{s})+$ 
$\mathrm{HCl}(\mathrm{aq})$ and the standard acidity constant of the ion $\mathrm{HSO}_{4}{ }^{-}$in synthetic sea water from

273.15 to $318.15 \mathrm{~K}$. The Journal of Chemical Thermodynamics, 22(2), 113-127. https://doi.org/10.1016/0021-9614(90)90074-Z

Dickson, A. G., Sabine, C. L. and Christian, J. R. (2007). Guide to Best Practices for Ocean $\mathrm{CO}_{2}$ Measurments. PICES Special Publication 3, $191 \mathrm{pp.}$

Doney, S. C., Fabry, V. J., Feely, R. A., and Kleypas, J. A. (2009). Ocean Acidification: the other $\mathrm{CO}_{2}$ problem. Annual Review of Marine Science, 1(1), 169-192. https://doi.org/10.1146/annurev.marine.010908.163834

Feely, R. A., Wanninkhof, R., Milburn, H. B., Cosca, C E., Stapp, M., and Murphy, P. P. (1998). A new automated underway system le making high precision $\mathrm{pCO}_{2}$ measurements onboard research ships. Analytica Chimica Acta, 377(2-3), 185-191. https://doi.org/10.1016/S0003-2670(98)073: ४-2

Frankignoulle, M., and Borges, A. V. ( $(2, n 1)$. European continental shelf as a significant sink for atmospheric carbon dioxide. Global Biogeochemical Cycles, 15(3), 569-576. https://doi.org/10.1029/2000rBC $\cong 307$

Friedlingstein, P., Jones, M. 'T', U'Sullivan, M., Andrew, R. M., Hauck, J., Peters, G. P., Peters, W., Pongratz I., Si.ch, S., Quéré, C., Bakker, D. C. E., Canadell, J. G., Ciais, P., Jackson, R. B., Aıthuni, P., Barbero, L., Bastos, A., Bastrikov, V., Becker, M., Bopp, L., Buitenhuis, E., Chandra, N., Chevallier, F., Chini, L. P., Currie, K. I., Feely, R. A., Gehlen, M., Gilfillan, D., Gkritzalis, T., Goll, D. S., Gruber, N., Gutekunst, S., Harris, I., Haverd, V., Houghton, R. A., Hurtt, G., Ilyina, T., Jain, A. K., Joetzjer, E., Kaplan, J. O., Kato, E., Klein Goldewijk, K., Korsbakken, J. I., Landschützer, P., Lauvset, S. K., Lefèvre, N., Lenton, A., Lienert, S., Lombardozzi, D., Marland, G., McGuire, P. C., Melton, J. R., Metzl, N., Munro, D. R., Nabel, J. E. M. S., Nakaoka, S., Neill, C., Omar, A. M., Ono, T., Peregon, A., Pierrot, D., Poulter, B., Rehder, G., Resplandy, L., 
Robertson, E., Rödenbeck, C., Séférian, R., Schwinger, J., Smith, N., Tans, P. P., Tian, H., Tilbrook, B., Tubiello, F. N., Van der Werf, G. R., Wiltshire, A. J., and Zaehle, S. (2019). Global Carbon Budget 2019. Earth System Science Data, 11(4), 1783-1838. https://doi.org/10.5194/essd-11-1783-2019

Gattuso, J.P., and Hansson, L. (2011). Ocean Acidification, Oxford University Press, 352 pp. González-Dávila, M., Santana-Casiano, J. M., Rueda, M. J., and Llinás, O. (2010). The water column distribution of carbonate system variables at the ESTOC site from 1995 to 2004. Biogeosciences, 7(10), 3067-3081. https://doi.org/10.519//hg. 7-3067-2010

González-Dávila, M., Santana-Casiano, J. M., Rueda, M..'., L'inás, O., and González-Dávila, E. F. (2003). Seasonal and interannual variability ni ea-surface carbon dioxide species at the European Station for Time Series in the G a an at the Canary Islands (ESTOC) between 1996 and 2000. Globa Ri,geochemical Cycles, 17(3), 1076. https://doi.org/10.1029/2002gb001:?3

Gruber, N., Clement, D., Carter, B. R., Feely, R. A., van Heuven, S., Hoppema, M., Ishii, M., Key, R. M., Kozyr, A., Lauv`at, c K., Lo Monaco, C., Mathis, J. T., Murata, A., Olsen, A., Pérez, F. F., Sabine, C. L., Tanhua, T., and Wanninkhof, R. (2019). The oceanic sink for anthropogenic rc. from 1994 to 2007. Science, 363(6432), 1193-1199. https://doi.org/10.1 'º/science.aau5153

Gruber, N., Keeling, C. D., and Stocker, T. F. (1998). Carbon-13 constraints on the seasonal inorganic carbon budget at the BATS site in the Northwestern Sargasso Sea. Deep-Sea Research Part I: Oceanographic Research Papers, 45(4-5), 673-717. https://doi.org/10.1016/S0967-0637(97)00098-8

Hagen, E., Zülicke, C., and Feistel, R. (1996). Near-surface structures in the Cape Ghir filament off Morocco. Oceanologica Acta, 19(6), 577-598.

Hernández-Guerra, A., Machín, F., Antoranz, A., Cisneros-Aguirre, J., Gordo, C., Marrero- 
Díaz, A., Martínez, A., Ratsimandresy, A.W., Rodríguez-Santana, A., Sangrá, P., LópezLaazen, F., Parrilla, G., and Pelegrí, J. L. (2002). Temporal variability of mass transport in the Canary Current. Deep-Sea Research Part II: Topical Studies in Oceanography, 49(17), 3415-3426. https://doi.org/10.1016/S0967-0645(02)00092-9

Huntsman, S. A., and Barber, R. T. (1977). Primary production off northwest Africa: the relationship to wind and nutrient conditions. Deep-Sea Research, 24(1), 25-33. https://doi.org/10.1016/0146-6291(77)90538-0

Jewell, P. W. (1994). Mass balance models of Ekman Transpent ans nutrient fluxes in coastal upwelling zones. Global Biogeochemical Cycles, 8(2), 165-177. https://doi.org/10.1029/94GB00097

Jing, Y., Li, Y., Xu, Y., and Fan, G. (2019). Influe nce of the NAO on the North Atlantic $\mathrm{CO}_{2}$ fluxes in winter and summer on the ntrannual scale. Advances in Atmospheric Sciences, 36(11), 1288-1298. https.."dr,1.org/10.1007/s00376-019-8247-2

Johnson, J., and Stevens, I. (2000). A fine resolution model of the eastern North Atlantic between the Azores, the Canary 'slands and the Gibraltar Strait. Deep-Sea Research

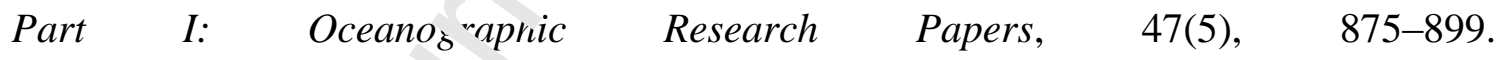
https://doi.org/10.1016/^nr 67-0637(99)00073-4

Khatiwala, S., Tanhua, T., Mikaloff Fletcher, S., Gerber, M., Doney, S. C., Graven, H. D., Gruber, N., McKinley, G. A., Murata, A., Ríos, A. F., and Sabine, C. L. (2013). Global ocean storage of anthropogenic carbon. Biogeosciences, 10(4), 2169-2191. https://doi.org/10.5194/bg-10-2169-2013

Knoll, M., Hernández-Guerra, A., Lenz, B., López Laatzen, F., Machín, F., Müller, T. J., and Siedler, G. (2002). The Eastern Boundary Current system between the Canary Islands and the African Coast. Deep-Sea Research Part II: Topical Studies in Oceanography, 49(17), 3427-3440. https://doi.org/10.1016/S0967-0645(02)00105-4 
Lee, K., Kim, T. W., Byrne, R. H., Millero, F. J., Feely, R. A., and Liu, Y. M. (2010). The universal ratio of boron to chlorinity for the North Pacific and North Atlantic oceans. Geochimica et Cosmochimica Acta, 74(6), 1801-1811. https://doi.org/10.1016/j.gca.2009.12.027

Lee, K., Tong, L. T., Millero, F. J., Sabine, C. L., Dickson, A. G., Goyet, C., Park, P., Wanninkhof, R., Feely, R. A., and Key, R. M. (2006). Global relationships of total alkalinity with salinity and temperature in surface waters of the world's oceans. Geophysical Research Letters, 33(19), 1-5. https://doi.or_'10.:029/2006GL027207

Lee, K., Wanninkhof, R., Feely, R. A., Millero, F. J. aı f Peng, T. H. (2000). Global relationships of total inorganic carbon with temnora . re and nitrate in surface seawater. Global Biogeochemical Cycles, 14(3), 979-994 hı``://doi.org/10.1029/1998GB001087 Le Quéré, C., Andrew, R. M., Friedlingstein, ?., s``h, S., Hauck, J., Pongratz, J., Pickers, P. A., Korsbakken, J. I., Peters, G. P., C.nadell, J. G., Arneth, A., Arora, V. K., Barbero, L., Bastos, A., Bopp, L., Chevallı־ F., Chini, L. P., Ciais, P., Doney, S. C., Gkritzalis, T., Goll, D. S., Harris, I., Herer V., Hoffman, F. M., Hoppema, M., Houghton, R. A., Hurtt, G., Ilyina, T., Jain, A. K., Johannessen, T., Jones, C. D., Kato, E., Keeling, R. F., Goldewijk, K. K., Lana``ü̈tzer, P., Lefèvre, N., Lienert, S., Liu, Z., Lombardozzi, D., Metzl, N., Munro, ?. K., Nabel, J. E. M. S., Nakaoka, S., Neill, C., Olsen, A., Ono, T., Patra, P., Peregon, A., Peters, W., Peylin, P., Pfeil, B., Pierrot, D., Poulter, B., Rehder, G., Resplandy, L., Robertson, E., Rocher, M., Rödenbeck, C., Schuster, U., Schwinger, J., Séférian, R., Skjelvan, I., Steinhoff, T., Sutton, A., Tans, P. P., Tian, H., Tilbrook, B., Tubiello, F. N., van der Laan-Luijkx, I. T., van der Werf, G. R., Viovy, N., Walker, A. P., Wiltshire, A. J., Wright, R., Zaehle, S., and Zheng, B. (2018). Global Carbon Budget 2018. Earth System Science Data, 10, 2141-2194, https://doi.org/10.5194/essd-10-21412018, 2018 
Leseurre, C., Lo Monaco, C., Reverdin, G., Metzl, N., Fin, J., Olafsdottir, S., and Racapé, V. (2020). Ocean carbonate system variability in the North Atlantic Subpolar surface water (1993-2017). Biogeosciences, 17(9), 2553-2577. https://doi.org/10.5194/bg-17-25532020

Lueker, T. J., Dickson, A. G., and Keeling, C. D. (2000). Ocean $\mathrm{pCO}_{2}$ calculated from dissolved inorganic carbon, alkalinity, and equations for $\mathrm{K}_{1}$ and $\mathrm{K}_{2}$ : Validation based on laboratory measurements of $\mathrm{CO}_{2}$ in gas and seawater at equilibrium. Marine Chemistry, 70(1-3), 105-119. https://doi.org/10.1016/S0304-4203(0ninuさ22-0

Lüger, H., Wallace, D. W. R., Körtzinger, A., and Nojiri, r. '2004). The $p \mathrm{CO}_{2}$ variability in the midlatitude North Atlantic Ocean during a fu'11 aı nual cycle. Global Biogeochemical Cycles, 18(3), 3023. https://doi.org/10.1029/20036:2002200

Mason, E., Colas, F., Molemaker, J., Shchepe`kı. 1.. F., Troupin, C., McWilliams, J. C., and Sangrà, P. (2011). Seasonal varia' 'il'`y of the Canary Current: A numerical study. Journal of Geophysical Research: Oceans, 116(6), 6001. https://doi.org/10.1029/2010 rrak j65

Mignot, J., de Boyer Montégu. C., Lazar, A., Cravatte, S., 2007. Control of salinity on the mixed layer depth in hs world ocean: 2. Tropical areas. Journal of Geophysical Research: Oceans. 1 1 L, 1-12. https://doi.org/10.1029/2006JC003954

Mintrop, L., Pérez, F. F., González-Dávila, M., Santana-Casiano, J. M., and Körtzinger, A. (2000). Alkalinity determination by potentiometry: Intercalibration using three different methods. Ciencias Marinas, 26(1), 23-37. https://doi.org/10.7773/cm.v26i1.573

Mittelstaedt, E. (1991). The ocean boundary along the northwest African coast: Circulation and oceanographic properties at the sea surface. Progress in Oceanography, 26(4), 307355. https://doi.org/10.1016/0079-6611(91)90011-A

Pastor, M. V., Pelegrí, J. L., Hernández-Guerra, A., Font, J., Salat, J., and Emelianov, M. 
(2008). Water and nutrient fluxes off Northwest Africa. Continental Shelf Research, 28(7), 915-936. https://doi.org/10.1016/j.csr.2008.01.011

Pelegrí, J. L., Arístegui, J., Cana, L., González-Dávila, M., Hernández-Guerra, A., Hernández-León, S., Marrero-Díaz, A., Montero, M. F., Sangrà, P., and SantanaCasiano, M. (2005). Coupling between the open ocean and the coastal upwelling region off northwest Africa: Water recirculation and offshore pumping of organic matter. Journal of Marine Systems, 54(1-4), 3-37. https://doi.org/10.1016/j.jmarsys.2004.07.003 Pérez-Rodríguez, P., Pelegrí, J. L., and Marrero-Díaz, A. (2nn1). Dynamical characteristics of the Cape Verde frontal zone. Scirntu Marina, 65, 241-250. https://doi.org/10.3989/scimar.2001.65s1241

Pierrot, D., Neill, C., Sullivan, K., Castle, R., Wan inı hof, R., Lüger, H., Johannessen, T., Olsen, A., Feely, R. A., and Cosca, C. E. (’'J09). Recommendations for autonomous underway $\mathrm{pCO}_{2}$ measuring systeı - nd data-reduction routines. Deep-Sea Research Part II: Topical Studies in Oceanography, 56(8-10), 512-522. https://doi.org/10.1016/j.dsr2?0( $\odot .12 .005$

Ruiz, S., Pelegrí, J. L., Emelia.'ov, M., Pascual, A., and Mason, E. (2014). Geostrophic and ageostrophic circulation $\sim$ a shallow anticyclonic eddy off Cape Bojador. Journal of Geophysical Kesearch: $\quad$ Oceans, $119(2), \quad 1257-1270$. https://doi.org/10.1002/2013JC009169

Sabine, C. L., Feely, R. A., Gruber, N., Key, R. M., Lee, K., Bullister, J. L., Wanninkhof, R., Wong, C. S., Wallace, D., Tilbrook, B., Millero, F. J., Peng, T., Kozyr, A., Ono, T., and Rios, A. F. (2004). The oceanic sink for anthropogenic $\mathrm{CO}_{2}$. Science, 305(5682), 367371. https://doi.org/10.1126/science.1097403

Sangrà, P., Pascual, A., Rodríguez-Santana, Á., Machín, F., Mason, E., McWilliams, J. C., Pelegrí, J. L., Dong, C., Rubio, A. M., Aristegui, J., Marrero-Díaz, A., Hernández- 
Guerra, A., Martínez-Marrero, A., and Auladell, M. (2009). The Canary Eddy Corridor: A major pathway for long-lived eddies in the subtropical North Atlantic. Deep-Sea Research Part I: Oceanographic Research Papers, 56(12), 2100-2114. https://doi.org/10.1016/j.dsr.2009.08.008

Santana-Casiano, J. M., González-Dávila, M., Laglera-Baquer, L. M., and RodriguezSomoza, M. J. (2001). Carbon dioxide system in the Canary region during October 1995. Scientia Marina, 65(S1), 41-49. https://doi.org/10.3989/scimar.2001.65s141

Santana-Casiano, J. M., González-Dávila, M., Rueda, M. J., I l’nás, O., and González-Dávila, E. F. (2007). The interannual variability of oceani,$\subset \boldsymbol{T}_{2}$ parameters in the northeast Atlantic subtropical gyre at the ESTOC site. Glohrl „riogeochemical Cycles, 21(1) 1015. https://doi.org/10.1029/2006GB002788

Sarmiento, J. L., and Gruber, N., (2006). Oc an Biogeochemical Dynamics. Cambridge University.

Shadwick, E. H., Thomas, H., Azetsu-_ott, K., Greenan, B. J. W., Head, E., and Horne, E. (2011). Seasonal variability of di c slved inorganic carbon and surface water $\mathrm{pCO}_{2}$ in the Scotian Shelf region of tì ' Northwestern Atlantic. Marine Chemistry, 124 (1-4), 23-37. https://doi.org/10.1016/J.m . .rchem.2010.11.004

Shadwick, E. H., Thon``s, H., Comeau, A., Craig, S. E., Hunt, C. W., and Salisbury, J. E. (2010). Air-Sea $\mathrm{CO}_{2}$ fluxes on the Scotian Shelf: seasonal to multi-annual variability. Biogeosciences, 7, 3851-3867. https://doi.org/10.5194/bg-7-3851-2010

Takahashi, T., Olafsson, J., Goddard, J. G., Chipman, D. W., and Sutherland, S. C. (1993). Seasonal variation of $\mathrm{CO}_{2}$ and nutrients in the high-latitude surface oceans: A comparative study. Global Biogeochemical Cycles, 7(4), 843-878. https://doi.org/10.1029/93GB02263

Takahashi, T., Sutherland, S. C., Sweeney, C., Poisson, A., Metzl, N., Tilbrook, B., Bates, N., 
Wanninkhof, R., Feely, R. A., Sabine, C., Olafsson, J., and Nojiri, Y. (2002). Global sea-air $\mathrm{CO}_{2}$ flux based on climatological surface ocean $\mathrm{pCO}_{2}$, and seasonal biological and temperature effects. Deep-Sea Research Part II: Topical Studies in Oceanography, 49(9-10), 1601-1622. https://doi.org/10.1016/S0967-0645(02)00003-6

Takahashi, T., Sutherland, S. C., Wanninkhof, R., Sweeney, C., Feely, R. A., Chipman, D. W., Hales, B., Friederich, G., Chávez, F., Sabine, C., Watson, A., Bakker, D. C. E., Schuster, U., Metzl, N., Yoshikawa-Inoue, H., Ishii, M., Midorikawa, T., Nojiri, Y., Körtzinger, A., Steinhoff, T., Hoppema, M., Olafsson, J Arı arson, T. S., Tilbrook, B., Johannessen, T., Olsen, A., Bellerby, R., Wong, C. ґ., זelille, D., Bates, N. R., and de Baar, H. J. W. (2009). Climatological mean and dec. tal change in surface ocean $\mathrm{pCO}_{2}$, and net sea-air $\mathrm{CO}_{2}$ flux over the global ocea is. Neep-Sea Research Part II: Topical Studies in Oceanograp.? $\quad$ 56(8-10), $\quad$ 554-577. https://doi.org/10.1016/j.dsr2.2008. ?.. ,09

Valdés, L., and Déniz-González, I. (¿ר15). Oceanographic and biological features in the Canary Current Large Marin` Ec $\backsim y$ stem. IOC-UNESCO, Paris, IOC Techni, 383.

Wanninkhof, R. (2014). Relati nship between wind speed and gas exchange over the ocean revisited. Limnolnoy and Oceanography: Methods, 12(6), 351-362. https://doi.org/10.4? Iy/lom.2014.12.351

Wanninkhof, R., and Feely, R. A. (1998). $f \mathrm{CO}_{2}$ dynamics in the Atlantic, South Pacific and South Indian oceans. Marine Chemistry, 60(1-2), 15-31. https://doi.org/10.1016/S03044203(97)00088-1

Weiss, R. F., and Price, B. A. (1980). Nitrous oxide solubility in water and seawater. Marine Chemistry, 8(4), 347-359. https://doi.org/10.1016/0304-4203(80)90024-9

Zenk, W., Klein, B., and Schroder, M. (1991). Cape Verde Frontal Zone. Deep Sea Research Part A. Oceanographic Research Papers, 38, S505-S530. 
https://doi.org/10.1016/s0198-0149(12)80022-7

Table 1. Annual and seasonal averages of SST, SSS, and $\mathrm{CO}_{2}$ system parameters and fluxes with their respective standard deviations on the GC-TNF, TNF-LNZ and CI-SG routes.

\begin{tabular}{|c|c|c|c|c|c|c|c|c|c|}
\hline & & $\begin{array}{l}\text { SST } \\
\left({ }^{\circ} \mathrm{C}\right)\end{array}$ & SSS & $\begin{array}{c}\mathbf{C}_{\mathrm{T}} \\
(\mu \mathrm{mol} \\
\left.\mathbf{k g}^{-1}\right)\end{array}$ & $\begin{array}{c}\mathrm{NC}_{\mathrm{T}} \\
(\mu \mathrm{mol} \\
\left.\mathrm{kg}^{-1}\right)\end{array}$ & $\begin{array}{c}f \mathrm{CO}_{2, \mathrm{~s}} \\
\mathrm{w} \\
(\mu \mathrm{atm}) \\
\end{array}$ & $\begin{array}{c}\mathrm{FCO}_{2} \\
\left(\mathrm{mmol} \mathrm{m}^{-} \mathbf{d}^{-1}\right)\end{array}$ & $\mathbf{p H}_{\mathbf{T}}$ & $\mathbf{p H}_{\mathrm{T}, 21}$ \\
\hline \multirow{5}{*}{$\begin{array}{l}\text { GC- } \\
\text { TNF }\end{array}$} & $\begin{array}{l}\text { Win } \\
\text { ter }\end{array}$ & $\begin{array}{r}19.21 \\
\pm 0.02\end{array}$ & $\begin{array}{r}36.796 \\
\pm 0.007\end{array}$ & $\begin{array}{c}2114.5 \\
5 \pm \\
0.41\end{array}$ & $\begin{array}{c}2109.1 \\
8 \pm \\
0.71\end{array}$ & $\begin{array}{l}378.00 \\
\pm 0.58\end{array}$ & $\begin{array}{c}-3.41 \pm \\
0.08\end{array}$ & $\begin{array}{c}8.077 \\
\pm \\
0.001\end{array}$ & $\begin{array}{c}8.049 \\
\pm \\
0.001\end{array}$ \\
\hline & $\begin{array}{c}\text { Spri } \\
\text { ng }\end{array}$ & $\begin{array}{r}19.95 \\
\pm 0.04\end{array}$ & $\begin{array}{r}36.730 \\
\pm 0.017\end{array}$ & $\begin{array}{c}2114.9 \\
5 \pm \\
0.72\end{array}$ & $\begin{array}{c}2113.0 \\
5 \pm \\
0.84\end{array}$ & $\begin{array}{l}393.19 \\
\pm 0.95\end{array}$ & $\begin{array}{c}-1.47 \pm \\
0.13\end{array}$ & $\begin{array}{c}8.064 \\
\pm \\
0.001\end{array}$ & $\begin{array}{c}8.047 \\
\pm \\
0.001\end{array}$ \\
\hline & $\begin{array}{l}\mathrm{Su} \\
\mathrm{mm} \\
\mathrm{er}\end{array}$ & $\begin{array}{r}22.36 \\
\pm 0.04\end{array}$ & $\begin{array}{r}36.796 \\
\pm 0.039\end{array}$ & $\begin{array}{c}2107.0 \\
1 \pm \\
2.19\end{array}$ & $\begin{array}{c}2101.7 \\
1 \pm \\
1.40\end{array}$ & $\begin{array}{l}420.15 \\
\pm 0.78\end{array}$ & $\begin{array}{c}2.15 \pm \\
0.07\end{array}$ & $\begin{array}{c}8.037 \\
\pm \\
0.001\end{array}$ & $\begin{array}{c}8.057 \\
\pm \\
0.001\end{array}$ \\
\hline & $\begin{array}{l}\text { Aut } \\
\text { umn }\end{array}$ & $\begin{array}{l}22.01 \\
\pm 0.05\end{array}$ & $\begin{array}{r}36.715 \\
\pm 0.019\end{array}$ & $\begin{array}{c}2101.8 \\
2 \pm \\
0.94\end{array}$ & $\begin{array}{c}2100.6 \\
3 \pm \\
1.08\end{array}$ & $\begin{array}{r}40.83 \\
-\quad 5.72\end{array}$ & $\begin{array}{c}0.14 \pm \\
0.13\end{array}$ & $\begin{array}{c}8.052 \\
\pm \\
0.001\end{array}$ & $\begin{array}{c}8.067 \\
\pm \\
0.001\end{array}$ \\
\hline & $\begin{array}{c}\text { Ann } \\
\text { ual }\end{array}$ & $\begin{array}{r}21.00 \\
\pm 0.04\end{array}$ & $\begin{array}{c}36.754 \\
\pm 0.020\end{array}$ & $\begin{array}{c}2108.7 \\
0 \pm \\
1.03\end{array}$ & $\begin{array}{c}210 \ldots \\
1.5 \\
1 . \iota^{21}\end{array}$ & $\begin{array}{l}399.20 \\
\pm 0.73\end{array}$ & $\begin{array}{c}-0.57 \pm \\
0.11\end{array}$ & $\begin{array}{c}8.057 \\
\pm \\
0.001\end{array}$ & $\begin{array}{c}8.056 \\
\pm \\
0.001\end{array}$ \\
\hline \multirow{5}{*}{$\begin{array}{c}\text { TNF } \\
- \\
\text { LNZ }\end{array}$} & $\begin{array}{l}\text { Win } \\
\text { ter }\end{array}$ & $\begin{array}{r}19.10 \\
\pm 0.04\end{array}$ & $\begin{array}{r}36.768 \\
\pm 0.009\end{array}$ & $\begin{array}{c}2115.0 \\
4 \pm \\
(.55\end{array}$ & $\begin{array}{c}-111.3 \\
1 \pm \\
0.94\end{array}$ & $\begin{array}{l}377.96 \\
\pm 0.84\end{array}$ & $\begin{array}{c}-2.78 \pm \\
0.10\end{array}$ & $\begin{array}{c}8.077 \\
\pm \\
0.001\end{array}$ & $\begin{array}{c}8.048 \\
\pm \\
0.001\end{array}$ \\
\hline & $\begin{array}{l}\text { Spri } \\
\text { ng }\end{array}$ & $\begin{array}{r}19.52 \\
\pm 0.04\end{array}$ & $\begin{array}{c}36.712 \\
\pm 0.00^{\circ}\end{array}$ & $\begin{array}{c}2110 . J \\
5 \pm \\
0.31\end{array}$ & $\begin{array}{c}2115.3 \\
7 \pm \\
0.51\end{array}$ & $\begin{array}{l}385.87 \\
\pm 0.70\end{array}$ & $\begin{array}{c}-3.00 \pm \\
0.11\end{array}$ & $\begin{array}{c}8.073 \\
\pm \\
0.001\end{array}$ & $\begin{array}{c}8.045 \\
\pm \\
0.001\end{array}$ \\
\hline & $\begin{array}{c}\mathrm{Su} \\
\mathrm{mm} \\
\mathrm{er}\end{array}$ & $\begin{array}{r}22.33 \\
\pm 0.06\end{array}$ & $\begin{array}{r}36 . .^{25} \\
\pm 0.6^{? 4}\end{array}$ & $\begin{array}{c}2107.3 \\
6 \pm \\
0.87\end{array}$ & $\begin{array}{c}2105.7 \\
4 \pm \\
1.26\end{array}$ & $\begin{array}{l}420.05 \\
\pm 0.81\end{array}$ & $\begin{array}{c}1.99 \pm \\
0.08\end{array}$ & $\begin{array}{c}8.037 \\
\pm \\
0.001\end{array}$ & $\begin{array}{c}8.057 \\
\pm \\
0.001\end{array}$ \\
\hline & $\begin{array}{l}\text { Aut } \\
\text { umn }\end{array}$ & $\begin{array}{c}22.11 \\
\pm 0.06\end{array}$ & $\begin{array}{r}31.754 \\
\pm 0.019\end{array}$ & $\begin{array}{c}2101.8 \\
7 \pm \\
0.63\end{array}$ & $\begin{array}{c}2098.6 \\
4 \pm \\
1.12\end{array}$ & $\begin{array}{l}402.98 \\
\pm 0.76\end{array}$ & $\begin{array}{c}0.04 \pm \\
0.13\end{array}$ & $\begin{array}{c}8.053 \\
\pm \\
0.001\end{array}$ & $\begin{array}{c}8.069 \\
\pm \\
0.001\end{array}$ \\
\hline & $\begin{array}{l}\text { Ann } \\
\text { ual }\end{array}$ & $\begin{array}{r}20.99 \\
\pm 0.05\end{array}$ & $\begin{array}{c}36.747 \\
\pm 0.016\end{array}$ & $\begin{array}{c}2108.7 \\
8 \pm \\
0.63\end{array}$ & $\begin{array}{c}2106.0 \\
6 \pm \\
1.03\end{array}$ & $\begin{array}{l}397.51 \\
\pm 0.77\end{array}$ & $\begin{array}{c}-0.80 \pm \\
0.11\end{array}$ & $\begin{array}{c}8.058 \\
\pm \\
0.001\end{array}$ & $\begin{array}{c}8.057 \\
\pm \\
0.001\end{array}$ \\
\hline \multirow{3}{*}{$\begin{array}{l}\text { CI- } \\
\text { SG }\end{array}$} & $\begin{array}{l}\text { Win } \\
\text { ter }\end{array}$ & $\begin{array}{r}18.15 \\
\pm 0.12\end{array}$ & $\begin{array}{r}36.595 \\
\pm 0.022\end{array}$ & $\begin{array}{c}2114.1 \\
5 \pm \\
0.96\end{array}$ & $\begin{array}{c}2120.5 \\
9 \pm \\
1.48\end{array}$ & $\begin{array}{l}370.31 \\
\pm 1.62\end{array}$ & $\begin{array}{c}-3.10 \pm \\
0.23\end{array}$ & $\begin{array}{c}8.084 \\
\pm \\
0.002\end{array}$ & $\begin{array}{c}8.040 \\
\pm \\
0.002\end{array}$ \\
\hline & $\begin{array}{l}\text { Spri } \\
\text { ng }\end{array}$ & $\begin{array}{r}18.60 \\
\pm 0.10\end{array}$ & $\begin{array}{r}36.418 \\
\pm 0.038\end{array}$ & $\begin{array}{c}2105.9 \\
4 \pm \\
3.43\end{array}$ & $\begin{array}{c}2122.4 \\
7 \pm \\
1.79\end{array}$ & $\begin{array}{l}382.90 \\
\pm 2.38\end{array}$ & $\begin{array}{c}-3.01 \pm \\
0.34\end{array}$ & $\begin{array}{c}8.070 \\
\pm \\
0.002\end{array}$ & $\begin{array}{c}8.033 \\
\pm \\
0.002\end{array}$ \\
\hline & $\begin{array}{c}\mathrm{Su} \\
\mathrm{mm} \\
\mathrm{er}\end{array}$ & $\begin{array}{r}22.09 \\
\pm 0.17 \\
\end{array}$ & $\begin{array}{r}36.580 \\
\pm 0.042\end{array}$ & $\begin{array}{c}2104.0 \\
7 \pm \\
2.88 \\
\end{array}$ & $\begin{array}{c}2112.4 \\
6 \pm \\
1.70 \\
\end{array}$ & $\begin{array}{l}420.70 \\
\pm 2.76\end{array}$ & $\begin{array}{c}1.57 \pm \\
0.24\end{array}$ & $\begin{array}{c}8.036 \\
\pm \\
0.002 \\
\end{array}$ & $\begin{array}{c}8.052 \\
\pm \\
0.002\end{array}$ \\
\hline
\end{tabular}




\begin{tabular}{|c|c|c|c|c|c|c|c|c|}
\hline $\begin{array}{l}\text { Aut } \\
\text { umn }\end{array}$ & $\begin{array}{r}20.79 \\
\pm 0.22\end{array}$ & $\begin{array}{r}36.650 \\
\pm 0.042\end{array}$ & $\begin{array}{c}2104.4 \\
7 \pm \\
1.53\end{array}$ & $\begin{array}{c}2107.5 \\
4 \pm \\
2.81\end{array}$ & $\begin{array}{l}394.50 \\
\pm 2.20\end{array}$ & $\begin{array}{c}-0.43 \pm \\
0.24\end{array}$ & $\begin{array}{c}8.061 \\
\pm \\
0.002\end{array}$ & $\begin{array}{c}8.057 \\
\pm \\
0.003\end{array}$ \\
\hline $\begin{array}{c}\text { Ann } \\
\text { ual }\end{array}$ & $\begin{array}{c}19.96 \\
\pm 0.16\end{array}$ & $\begin{array}{c}36.582 \\
\pm 0.036\end{array}$ & $\begin{array}{c}2107.4 \\
2 \pm \\
1.97 \\
\end{array}$ & $\begin{array}{c}2115.0 \\
3 \pm \\
2.03\end{array}$ & $\begin{array}{l}389.99 \\
\pm 2.17\end{array}$ & $\begin{array}{c}-1.34 \pm \\
0.25\end{array}$ & $\begin{array}{c}8.065 \\
\pm \\
0.002\end{array}$ & $\begin{array}{c}8.047 \\
\pm \\
0.003 \\
\end{array}$ \\
\hline
\end{tabular}

Table 2. Ratios T/B obtained at the selected stations on the GC-TNF, TNF-LNZ and CI-SG routes.

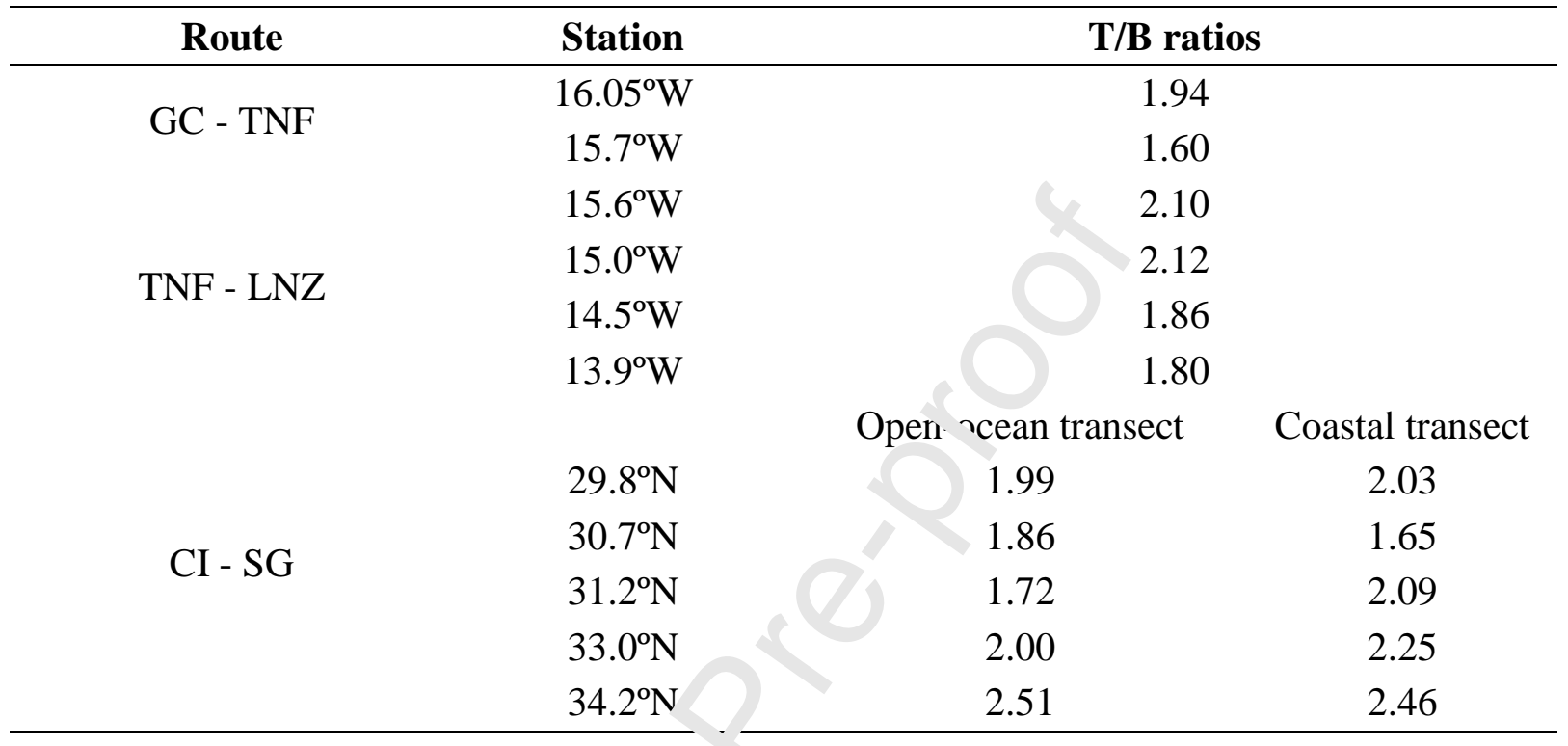

Table 3. Linear relationships of $f \mathrm{CO}_{2, \mathrm{sw}}-\mathrm{SST}$ and of $f \mathrm{CO}_{2, \mathrm{sw}}-\mathrm{pH}_{\mathrm{T}}$ in the winter-summer and February-October periods with their re ${ }_{1}$ ective standard deviations.

\begin{tabular}{|c|c|c|c|c|c|}
\hline \multirow[t]{2}{*}{$\begin{array}{c}\text { Rout } \\
\text { e } \\
\end{array}$} & \multirow{2}{*}{$\begin{array}{c}\text { Period } \\
\text { Winter - }\end{array}$} & \multicolumn{2}{|c|}{$\begin{array}{c}f \mathrm{CO}_{2}\left(\mu \rho^{+} \mathrm{m}\right)-\text { iST }\left({ }^{\circ} \mathrm{C}\right) \\
\text { re ationship }\end{array}$} & \multicolumn{2}{|c|}{$\begin{array}{c}f \mathrm{CO}_{2}(\mu \mathrm{atm})-\mathrm{pH}_{\mathrm{T}}(\text { total scale }) \\
\text { relationship }\end{array}$} \\
\hline & & $\left.f \mathrm{CO}_{2}=\right\urcorner . \overline{( \pm 0.31)}$ & $\mathrm{R}^{2}$ & $f \mathrm{CO}_{2}=-0.0009\left( \pm 1.57 \times 10^{-6}\right)$ & $\mathrm{R}^{2}=$ \\
\hline GC - & & $\mathrm{SST}+14$ & & & 0.999 \\
\hline TNF & & $f \mathrm{CO}=1$ & $\mathrm{R}^{2}=$ & $f \mathrm{CO}_{2}=-0$. & $\mathrm{R}^{2}=$ \\
\hline & & $\begin{array}{l}\mathrm{SS} \Gamma+8 \\
\Omega^{\prime}()_{2}=1\end{array}$ & & SS & $\begin{array}{l}0.999 \\
\mathrm{R}^{2}=\end{array}$ \\
\hline TNF - & & $\mathrm{SST}+16$ & 0.887 & SST & 0.999 \\
\hline LNZ & & $f \mathrm{CO}_{2}=\mathrm{c}$ & $\mathrm{R}^{2}$ & $f \mathrm{CO}_{2}=-0$ & $\mathrm{R}^{2}=$ \\
\hline & & $\begin{array}{l}\mathrm{SST}+195 \\
f \mathrm{CO}_{2}=11\end{array}$ & $\begin{array}{l}0.897 \\
\mathrm{R}^{2}=\end{array}$ & $\begin{array}{c}\mathrm{SST}+ \\
\mathrm{fCO}_{2}=-(\end{array}$ & $\begin{array}{l}0.999 \\
\mathrm{R}^{2}=\end{array}$ \\
\hline CI - & & $\mathrm{SST}+16$ & 0.864 & $\mathrm{SST}+8$ & 0.996 \\
\hline SG & & $f \mathrm{CO}_{2}=10$ & $\mathrm{R}^{2}=$ & $f \mathrm{CO}_{2}=-0$ & $\mathrm{R}^{2}=$ \\
\hline & - October & SST + $186.13( \pm 3.44)$ & 0.912 & $\mathrm{SST}+8.43\left( \pm 1.10 \times 10^{-3}\right)$ & 0.997 \\
\hline
\end{tabular}

Table 4. Net contribution on $\mathrm{NC}_{\mathrm{T}}$ temporal variation $\left(\Delta \mathrm{NC}_{\mathrm{T}} / \mathrm{dt}\right)$ of net community production $\left(\Delta \mathrm{NC}_{\mathrm{T}} /\left.\mathrm{dt}\right|_{\mathrm{NCP}}\right)$, air-sea exchange $\left(\Delta \mathrm{NC}_{\mathrm{T}} /\left.\mathrm{dt}\right|_{\mathrm{EX}}\right)$ and horizontal transport $\left(\Delta \mathrm{NC}_{\mathrm{T}} / \mathrm{dt}_{\mathrm{TRSP}}\right)$ in March-June (spring), June-September (summer) and February-October.

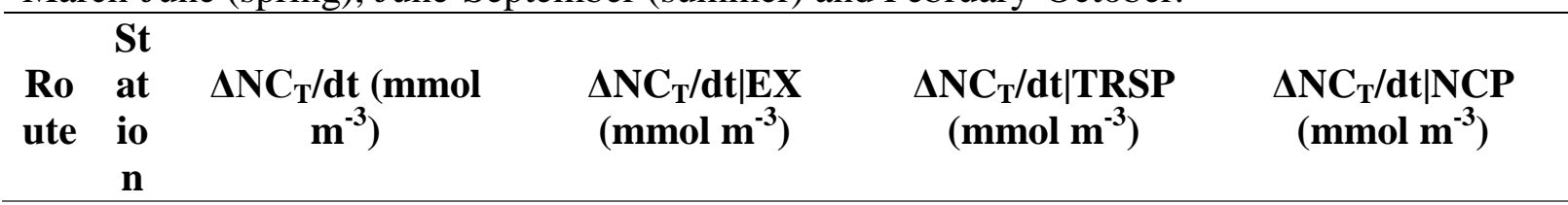




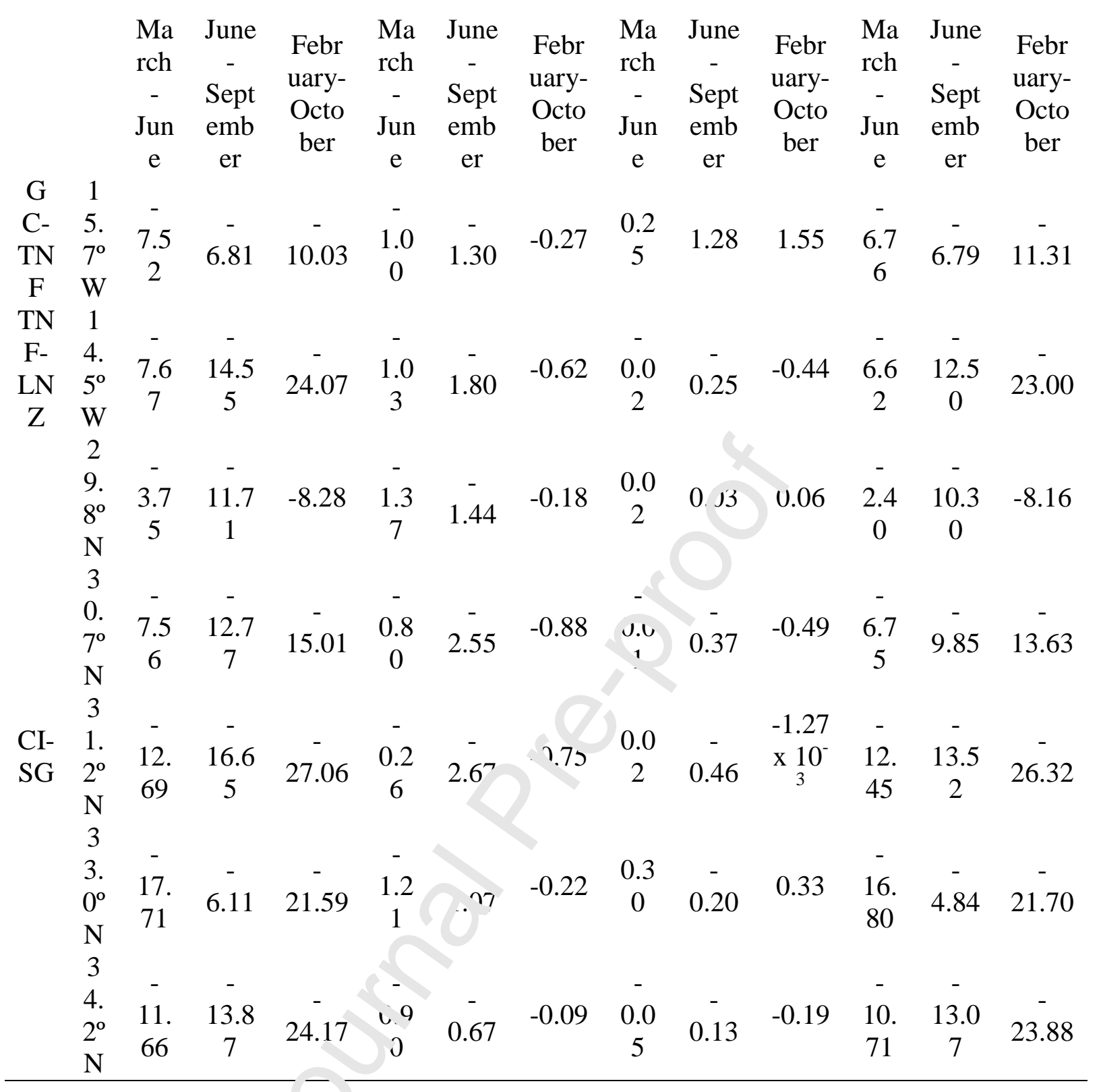

Figure 1. VOS routes in the region of interest in the Northeast Atlantic. Inter-insular routes between Gran Canaria and Tenerife (GC-TNF) and between Tenerife and Lanzarote (TNFLNZ) monitor the easternmost part of the Canary basin, while the Canary Islands-Strait of Gibraltar route (CI-SG) monitors the transition zone between coastal and open-ocean waters along northwest Africa. Points marked on the inter-island routes locate the ship's docking ports of Las Palmas de Gran Canaria (GC, red), Santa Cruz de Tenerife (TNF, green) and Arrecife (LNZ, yellow). 
Figure 2. Annual and seasonal averages of SST, $\mathrm{SSS}$ and $\mathrm{CO}_{2}$ system parameters and fluxes every $0.05^{\circ}$ of longitude on the GC-TNF route (left) and every $0.1^{\circ}$ of longitude on the TNFLNZ routes (right).

Figure 3. Seasonal variability of average (a) SST, (b) SSS and $\mathrm{CO}_{2}$ system parameters ((c) $\mathrm{C}_{\mathrm{T}}$, (d) $\mathrm{NC}_{\mathrm{T}}$, (e and f) $f \mathrm{CO}_{2, \mathrm{sw}}$, (g) $\mathrm{FCO}_{2}$ and (h) $\mathrm{pH}_{\mathrm{T}}$ and $\mathrm{pH}_{\mathrm{T}, 21}$ ) at $16.05 \pm 0.1^{\circ} \mathrm{W}$ (blue) and $15.7 \pm 0.1^{\circ} \mathrm{W}$ (red) along the GC-TNF route.

Figure 4. Seasonal variability of average (a) SST, (b) SSS and $\mathrm{CO}_{2}$ system parameters ((c) $\mathrm{C}_{\mathrm{T}}$, (d) $\mathrm{NC}_{\mathrm{T}}$, (e-h) $f \mathrm{CO}_{2, \mathrm{sw}}$, (i) $\mathrm{FCO}_{2}$ and (j) $\mathrm{pH}_{\mathrm{T}}$ and $\mathrm{pH}_{\mathrm{T}, 21}$ ) $+1.6 \pm 0.1^{\circ} \mathrm{W}$ (blue), $15.0 \pm$ $0.1^{\circ} \mathrm{W}$ (red), $14.5 \pm 0.1^{\circ} \mathrm{W}$ (green) and $13.9 \pm 0.1^{\circ} \mathrm{W}$ (blacl) ai nng the TNF-LNZ route.

Figure 5. Annual and seasonal averages of SST, SSS $n_{4} \mathrm{CO}_{2}$ system parameters and fluxes every $0.25^{\circ}$ of latitude on the CI-SG route.

Figure 6. Seasonal variability of average $\mathrm{SST}, \mathrm{r}^{\prime} \mathrm{J}_{2, \mathrm{sw}}, \mathrm{FCO}_{2}$ and $\mathrm{pH}_{\mathrm{T}}$ in open-ocean and coastal waters at points of interest on th. $\mathrm{C}_{-}-\mathrm{SG}$ route located at $29.8 \pm 0.2^{\circ} \mathrm{N}, 30.7 \pm 0.2^{\circ} \mathrm{N}$, and $33.0 \pm 0.2^{\circ} \mathrm{N}$.

Figure 7. Temporal and longitudinal distribution of the $f \mathrm{CO}_{2, \mathrm{sw}}$ values available in SOCAT (left) and obtained by the Canc 4-VOS line (right) in Cape Ghir latitude. Seasonality is given by the harmonic fitting functs $n$ represented below in red, which is available in Table A.2.

Figure 8. Temporal val ${ }^{\prime}$ iun of $\mathrm{NC}_{\mathrm{T}}\left(\Delta \mathrm{NC}_{\mathrm{T}} / \mathrm{dt}\right.$; black $)$ and relative contribution of the terms of net community production $\left(\Delta \mathrm{NC}_{\mathrm{T}} /\left.\mathrm{dt}\right|_{\mathrm{NCP}}\right.$; green $)$, air-sea exchange $\left(\Delta \mathrm{NC}_{\mathrm{T}} /\left.\mathrm{dt}\right|_{\mathrm{EX}}\right.$; blue $)$ and horizontal transport $\left(\Delta \mathrm{NC}_{\mathrm{T}} /\left.\mathrm{dt}\right|_{\mathrm{TRSP}}\right.$; red) from February to October. The net contribution of each term in spring, summer and February-October is shown in Table 4.

Figure 9. Annual average of $\mathrm{FCO}_{2}$ (gray), $\Delta f \mathrm{CO}_{2}$ (red) and wind speed (blue) for each route, calculated with spatial distribution every $0.05^{\circ}$ of longitude on the GC-TNF route, $0.1^{\circ}$ of longitude on the TNF-LNZ route and $0.25^{\circ}$ of latitude on the CI-SG route. 
Graphical abstract

Highlights

- The SST controls the seasonal and spatial variation of $\mathrm{CO}_{2}$ fugacity and fluxes.

- The $\mathrm{pH}$ and $f \mathrm{CO}_{2}$ shows spatial variability associated with upwelling influence.

- $\quad \mathrm{NC}_{\mathrm{T}}$ variation was mainly governed by biological activity and slightly affected by airsea fluxes.

- During 2019, the Northeast Atlantic region behaved a, a. aınnual $\mathrm{CO}_{2}$ sink of $-2.65 \pm$ $0.44 \mathrm{Tg} \mathrm{CO}_{2} \mathrm{yr}^{-1}$.

- VOS lines are a powerful tool to study de $\frown \frown_{2}$ system and fluxes in the coastal surface area. 

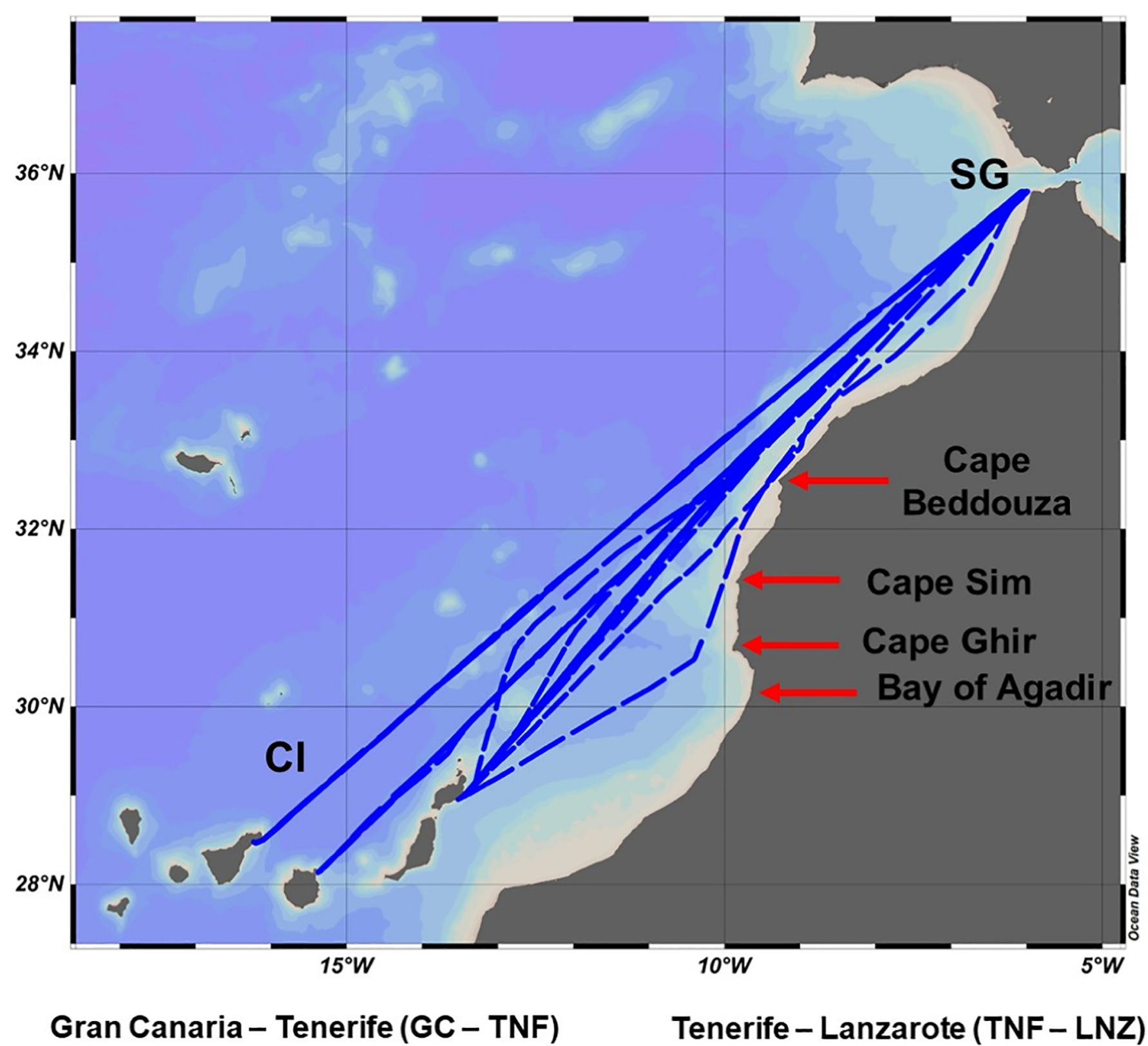

Tenerife - Lanzarote (TNF - LNZ)
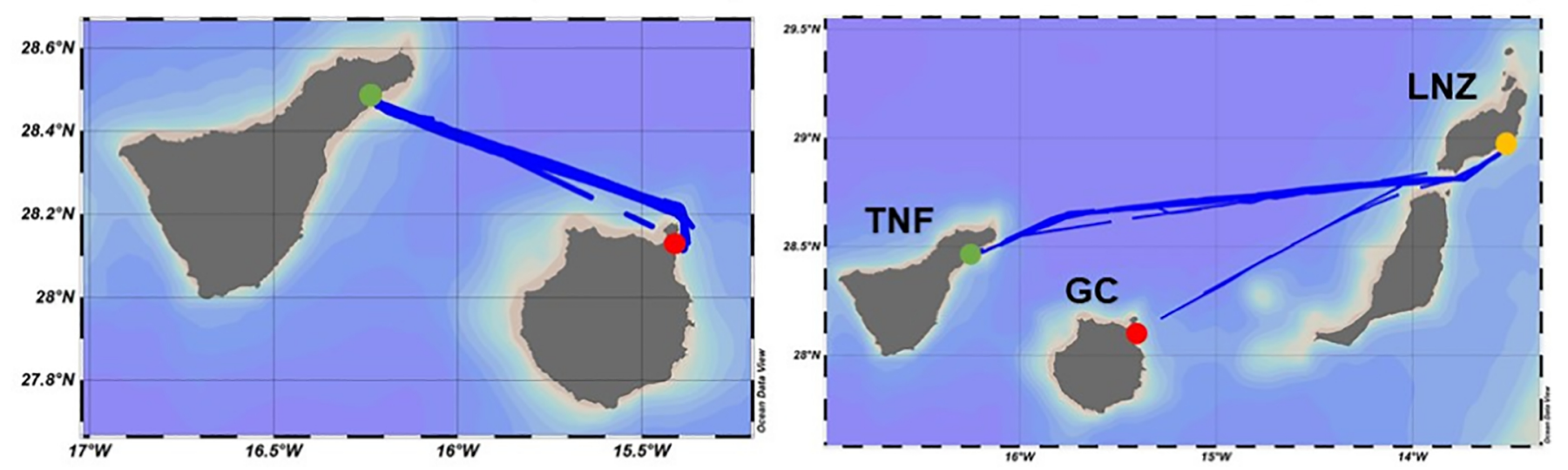
GC - TNF

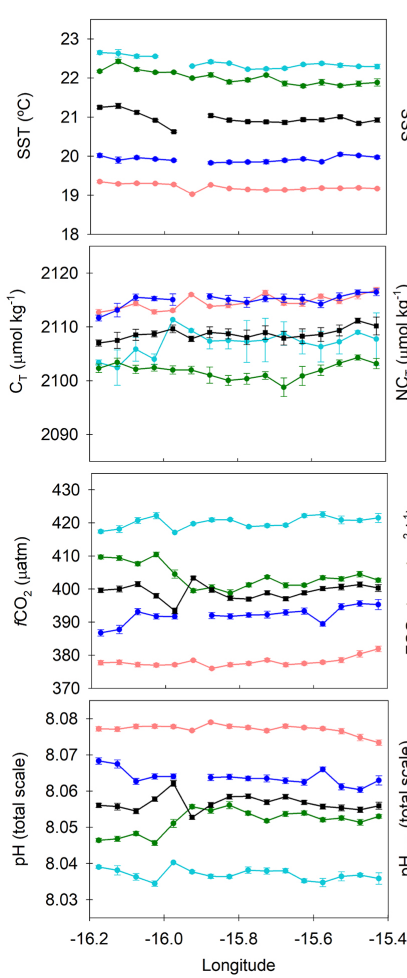

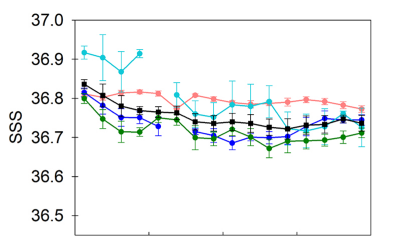
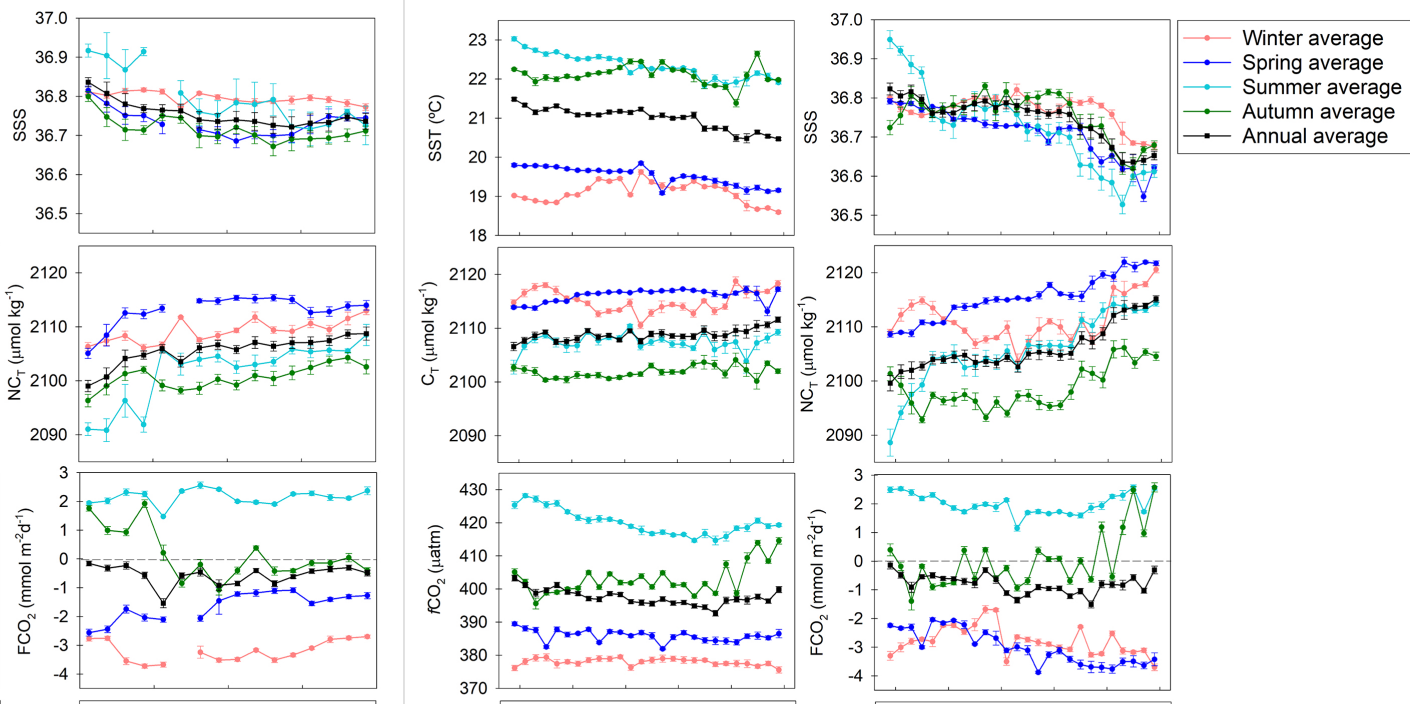
Annual average
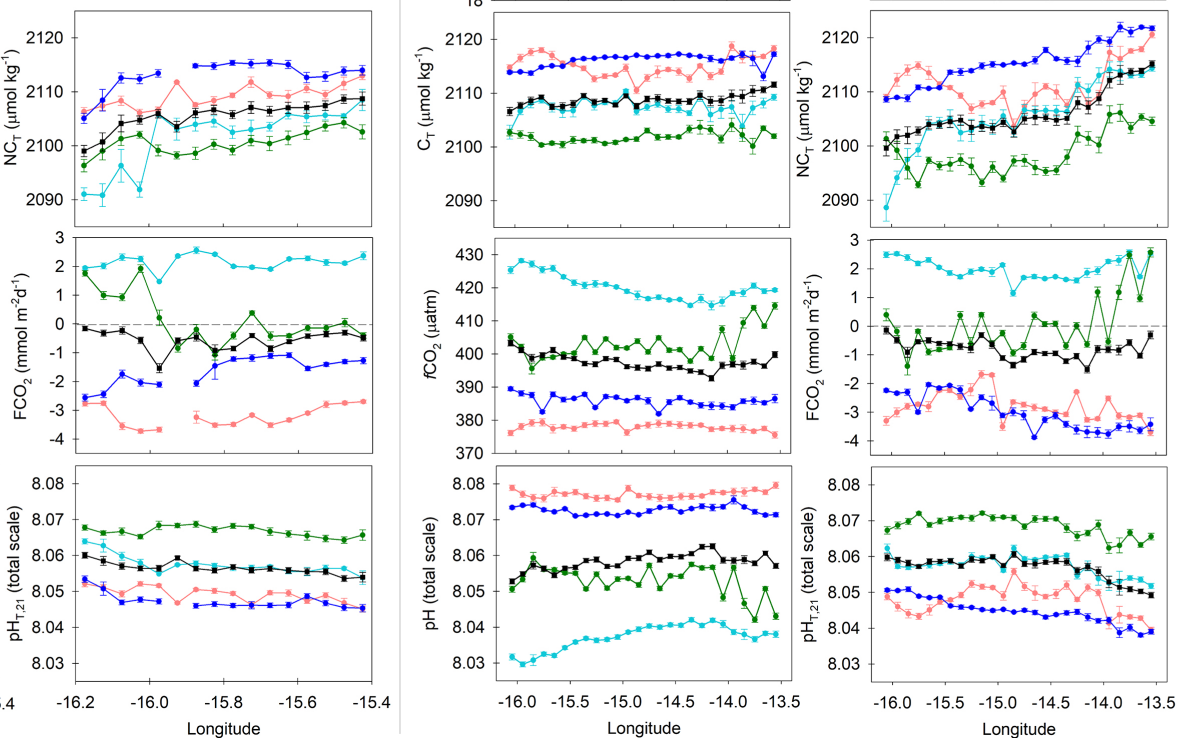

Figure 2 
Date

$\begin{array}{lllllll}1 / 10 & 1 / 1 & 1 / 4 & 1 / 7 & 1 / 10 & 1 / 1 & 1 / 4\end{array}$
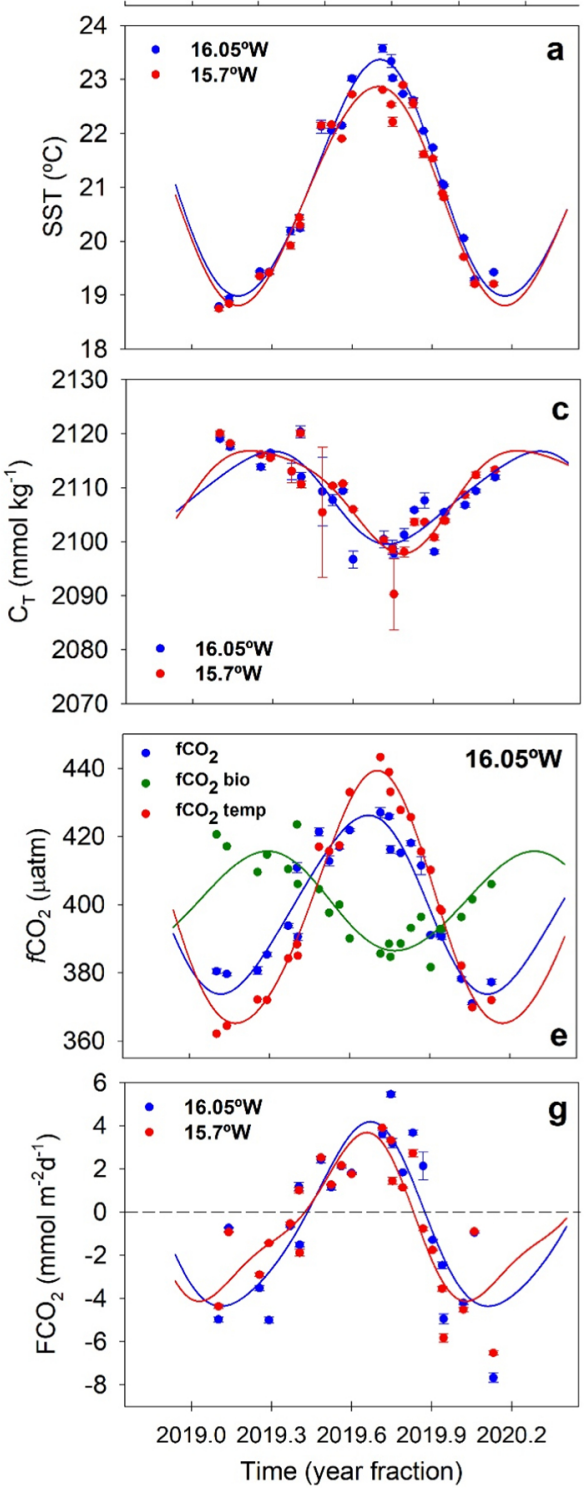

Date

$\begin{array}{lllllll}1 / 10 & 1 / 1 & 1 / 4 & 1 / 7 & 1 / 10 & 1 / 1 & 1 / 4\end{array}$
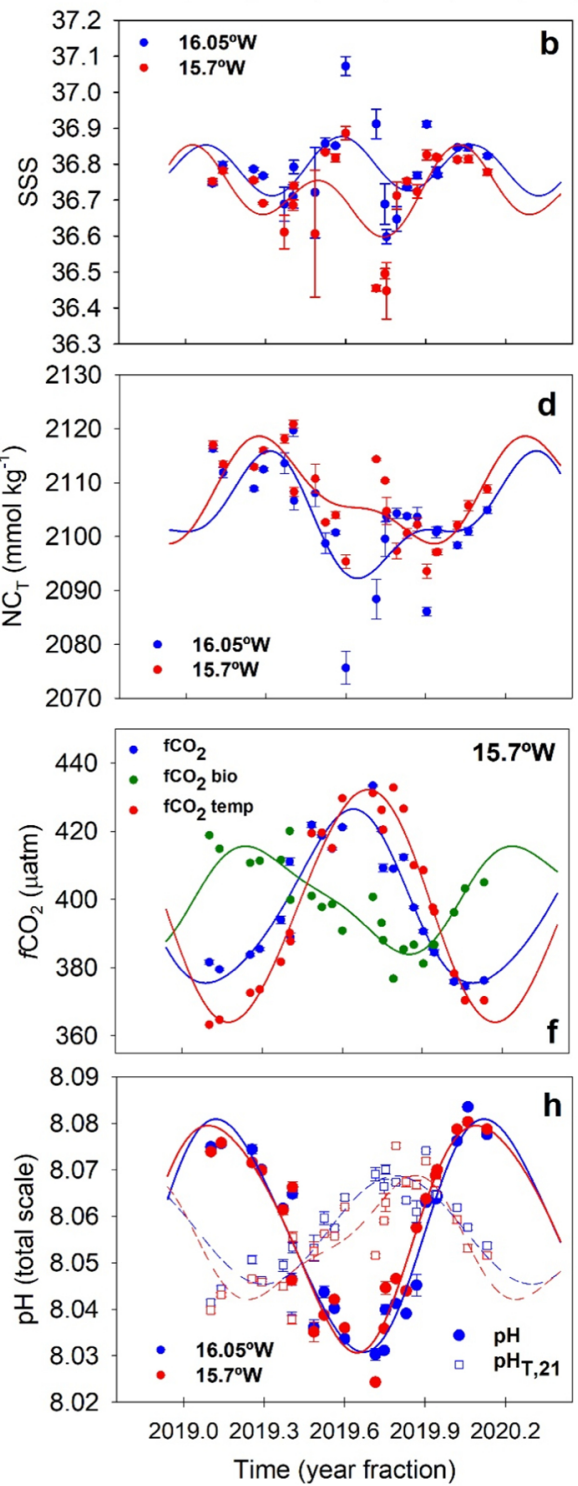

Figure 3 
Date

$\begin{array}{lllllll}1 / 10 & 1 / 1 & 1 / 4 & 1 / 7 & 1 / 10 & 1 / 1 & 1 / 4\end{array}$
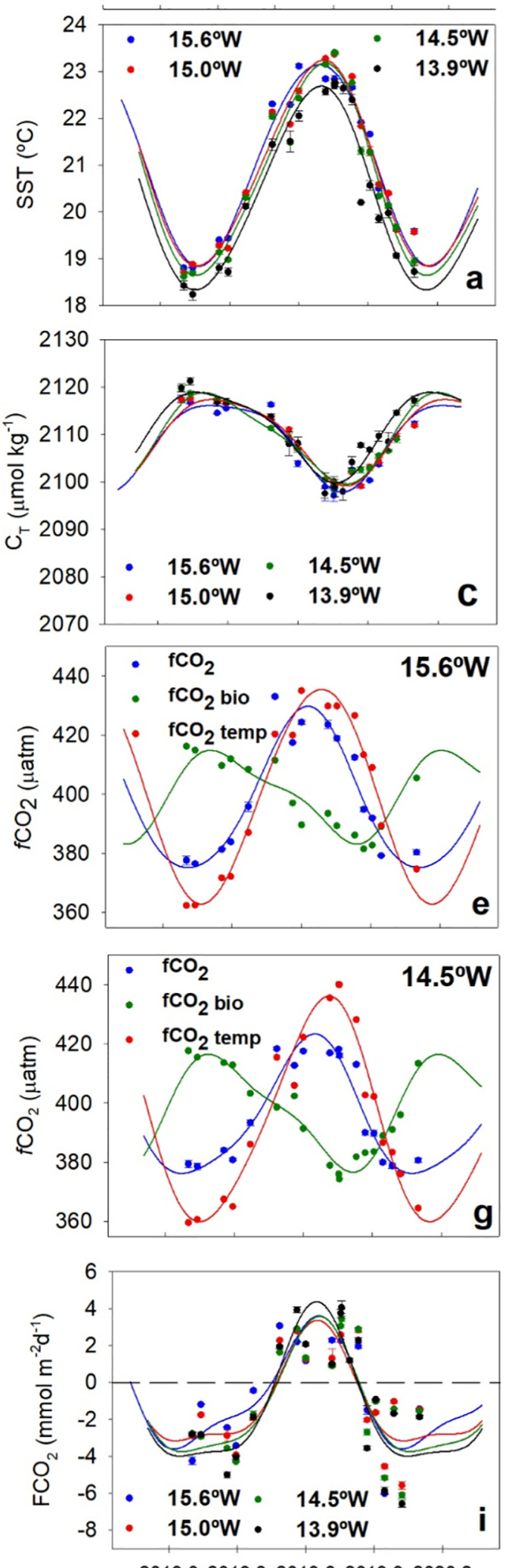

2019.02019 .32019 .62019 .92020 .2

Time (year fraction) $\begin{array}{lllllll}1 / 10 & 1 / 1 & 1 / 4 & 1 / 7 & 1 / 10 & 1 / 1 & 1 / 4\end{array}$

37.2

37.1

37.0

36.9

() 36.8

ल 36.7

36.6

36.5

36.4

36.3

b
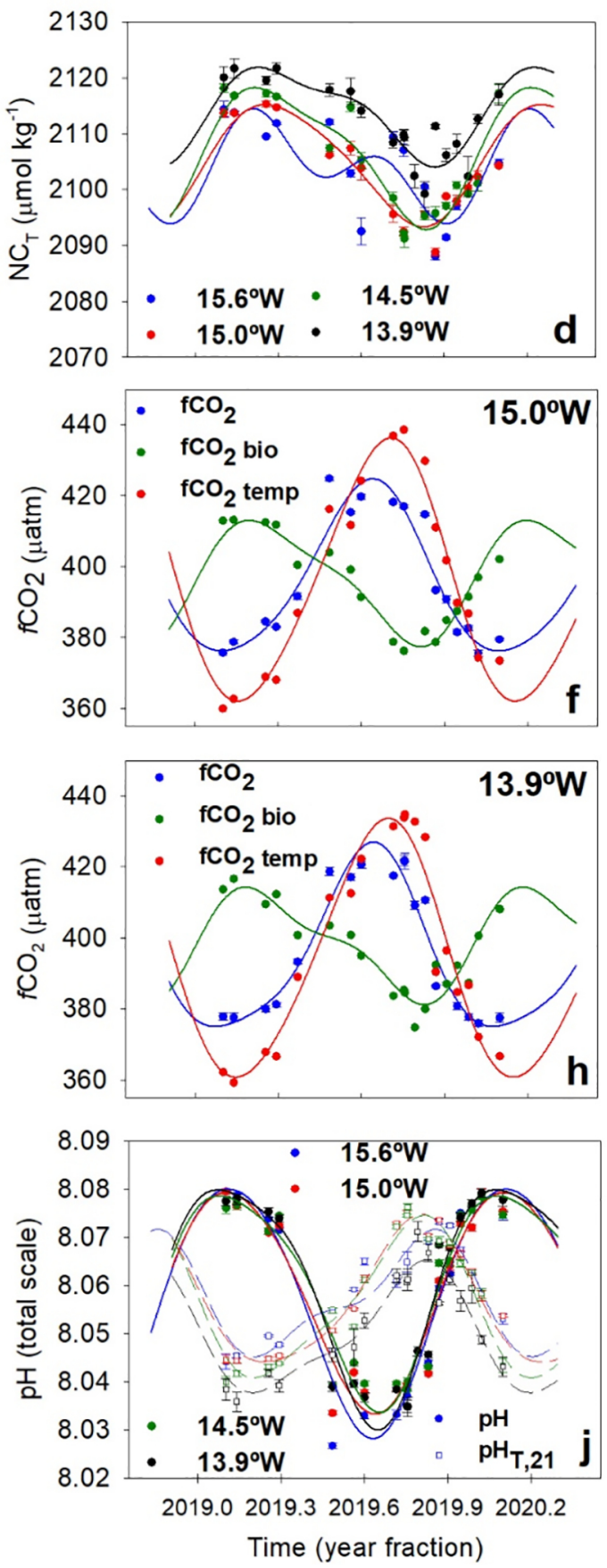
Cl - SG
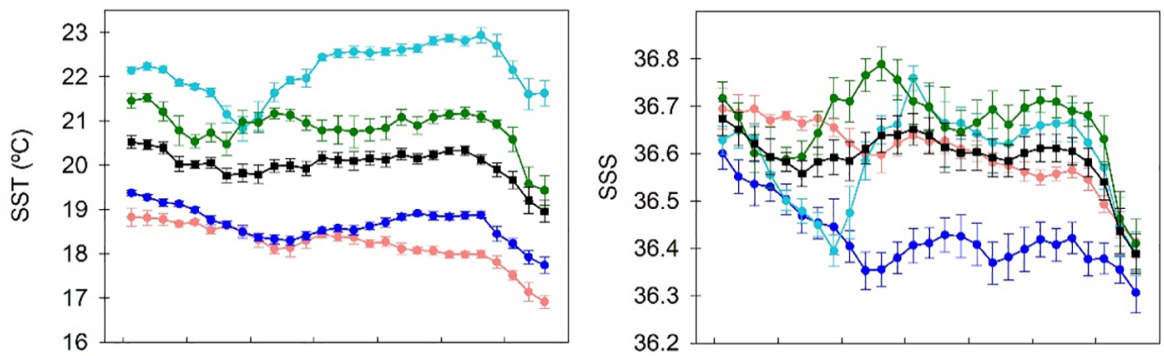

-Winter average

- Spring average

$\longrightarrow$ Summer average

— Autumn average

Annual average
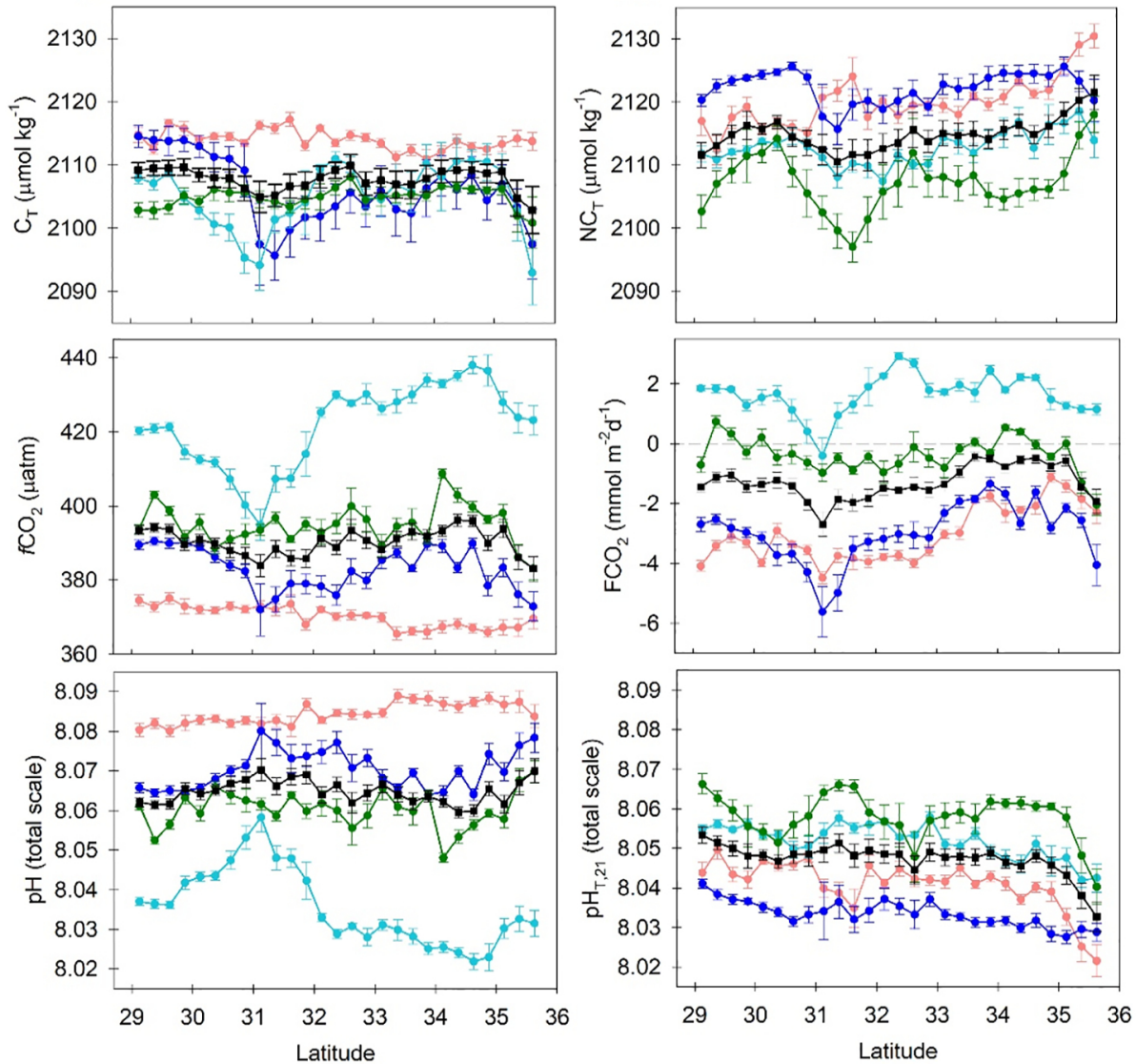

Figure 5 


\section{$29.8^{\circ} \mathrm{N}$}

Date

$1 / 121 / 03$ 1/06 1/09 1/12 1/03 1/06

24

- 14.65-12.65 $\mathrm{W}$

$\begin{array}{ll}\widehat{U} & 22 \\ \text { ๖ } & 20\end{array}$

18

16
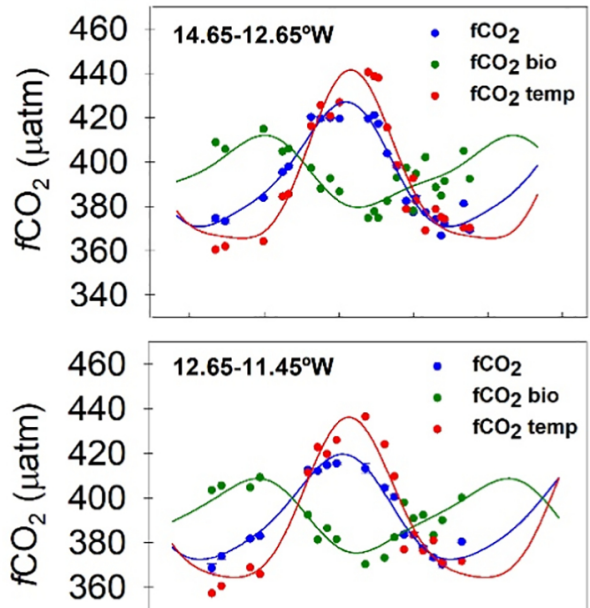

340

Tัॅ

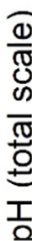

8.10

8.08

8.06

8.04

8.02

8.00

7.98 $30.7^{\circ} \mathrm{N}$

Date

$1 / 121 / 03$ 1/06 1/09 1/12 1/03 1/06
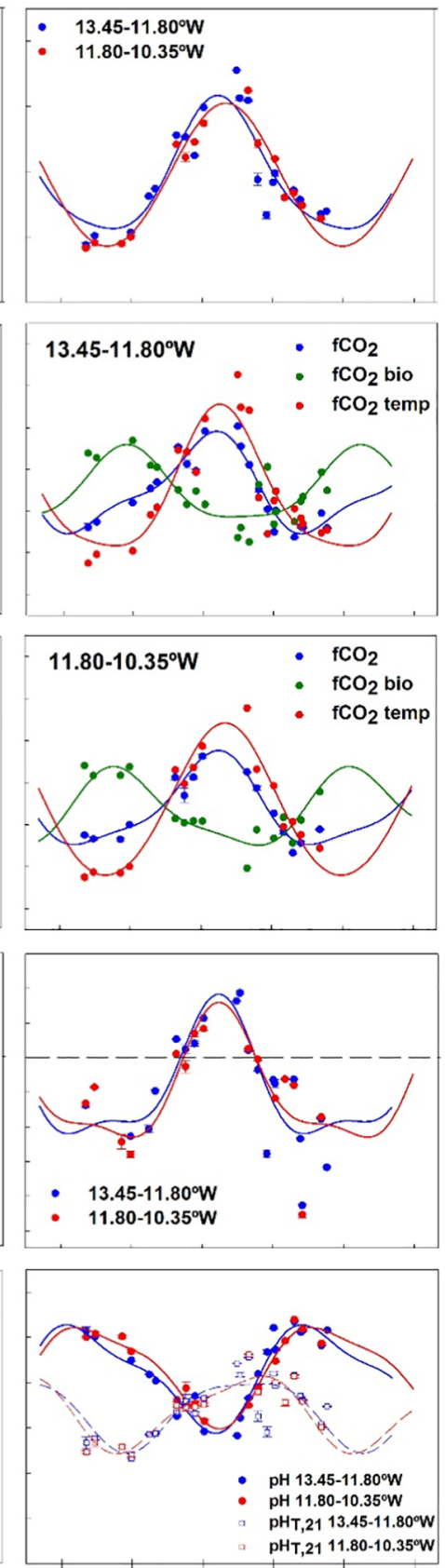

2019.02019 .32019 .62019 .92020 .22020 .5

Time (year fraction)
2019.02019 .32019 .62019 .92020 .22020 .5

Time (year fraction) $33.0^{\circ} \mathrm{N}$

Date

$1 / 121 / 031 / 061 / 091 / 121 / 031 / 06$
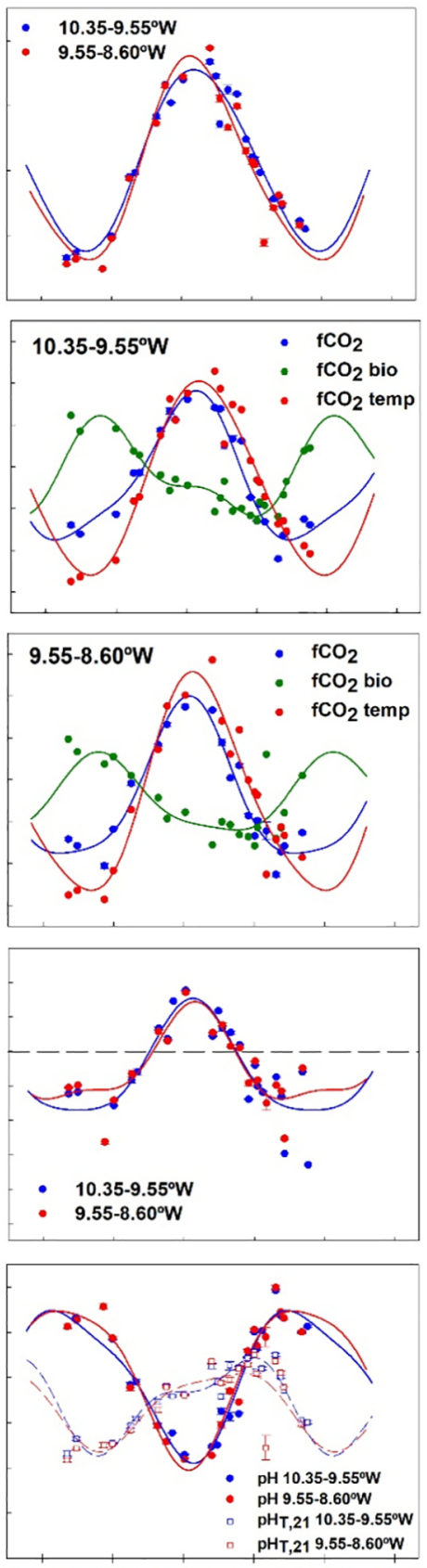

2019.02019 .32019 .62019 .92020 .22020 .5

Time (year fraction) 

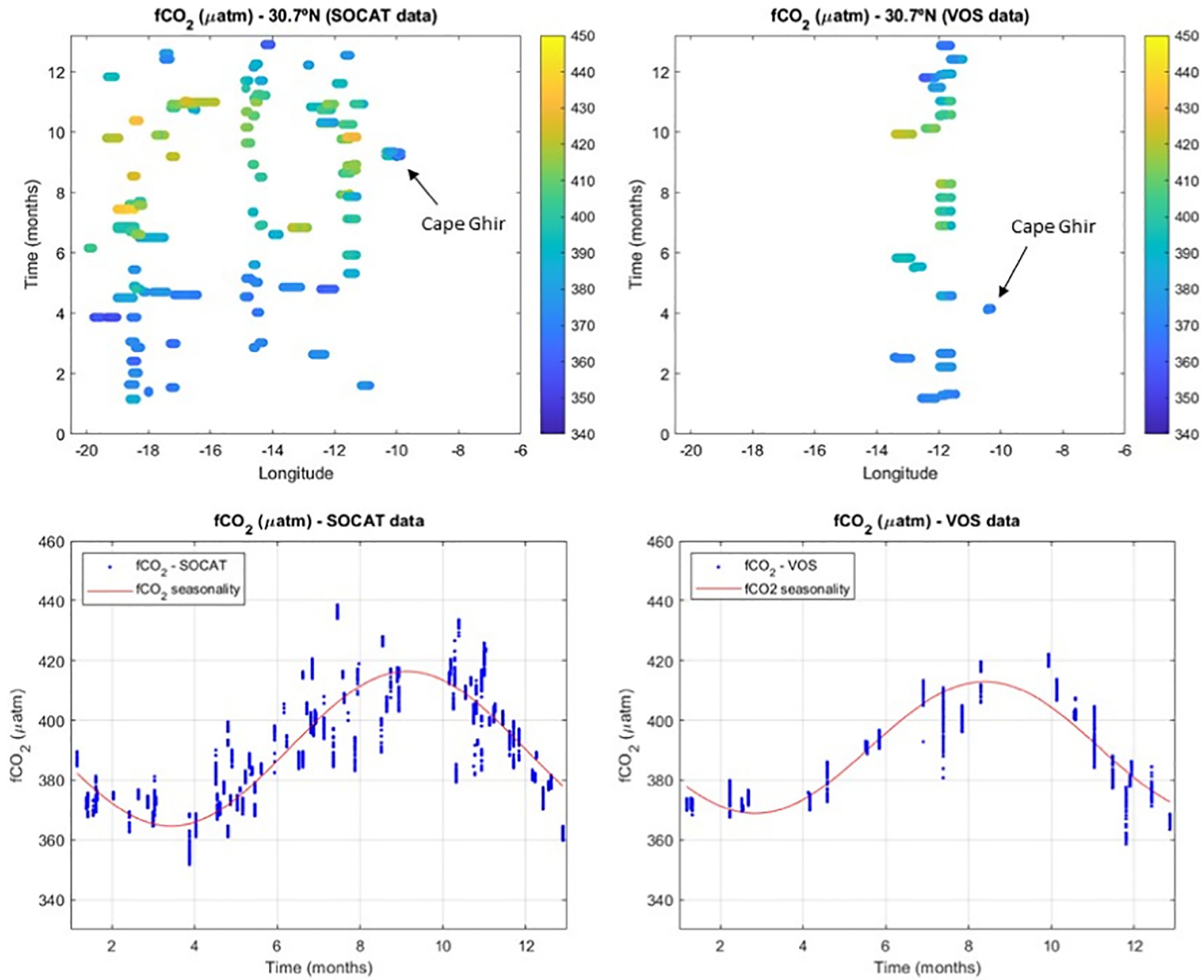

Figure 7 

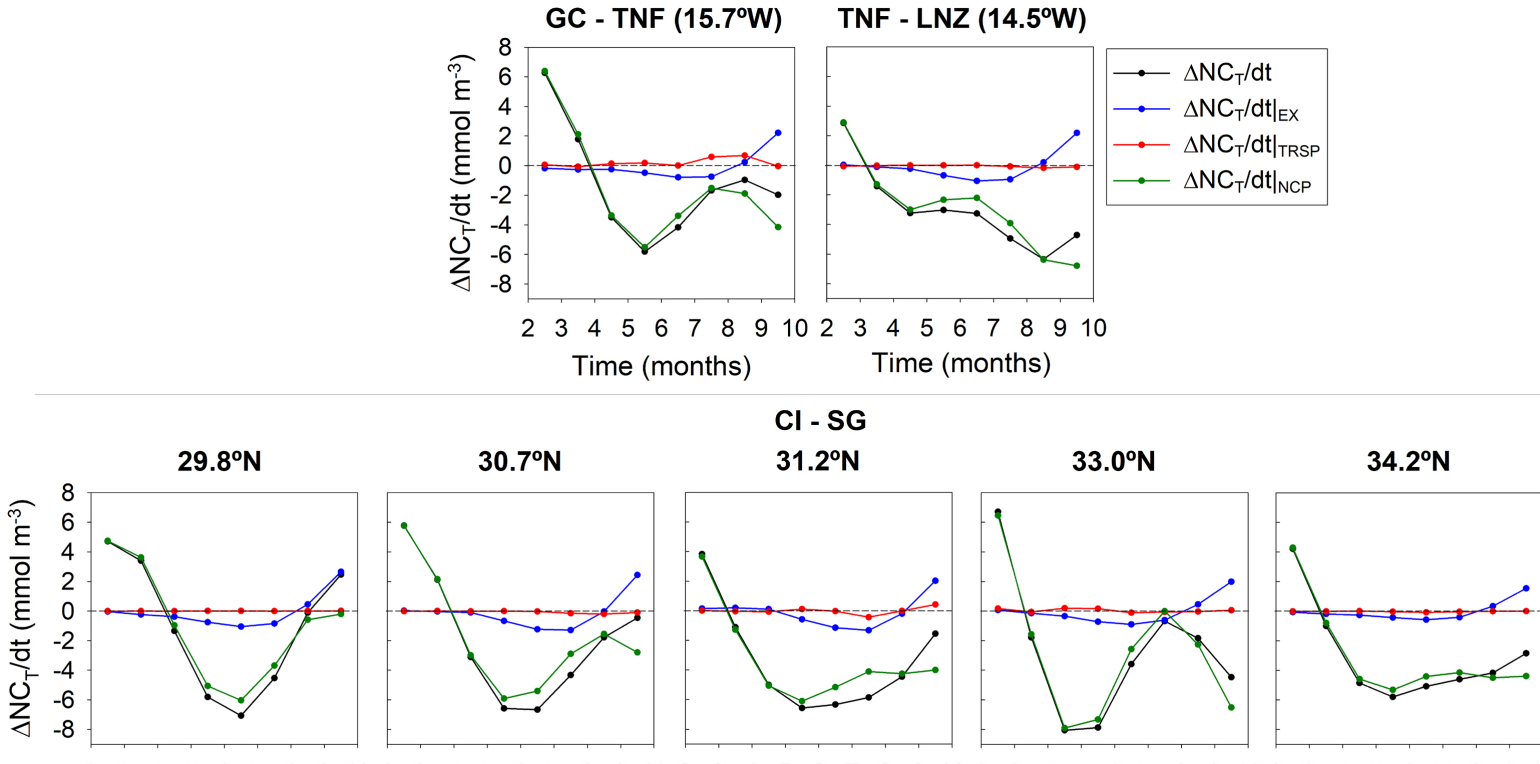

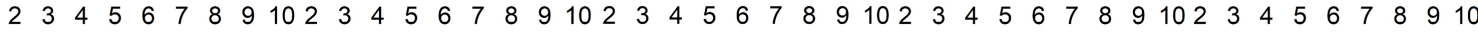 Time (months) Time (months) Time (months) Time (months) Time (months)

Figure 8 


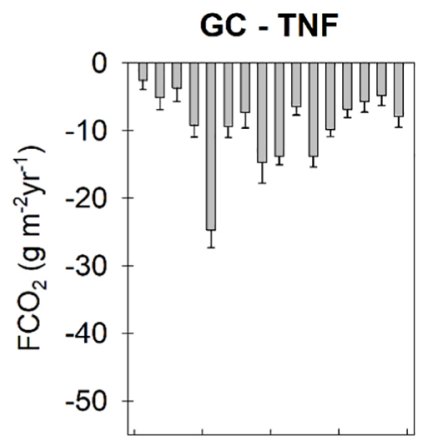

TNF - LNZ
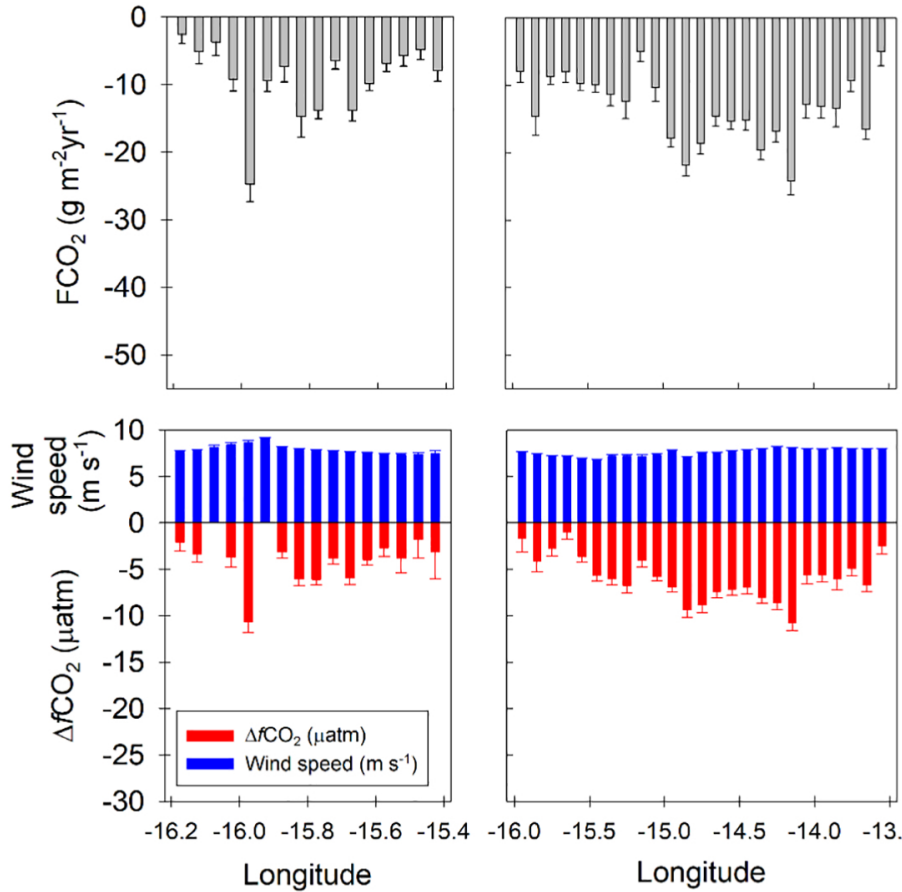
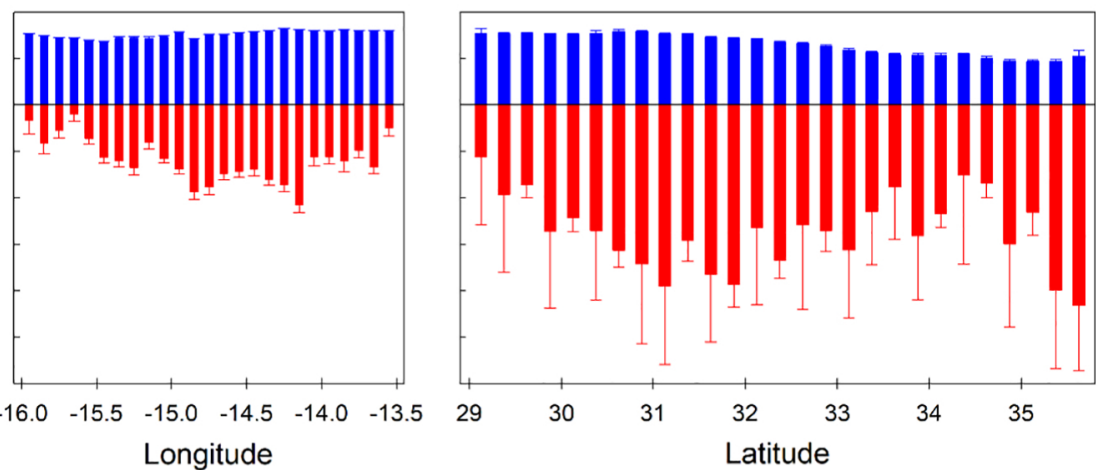

Figure 9 